\title{
IN PRAISE OF PUBLIC ACCESS: WHY THE GOVERNMENT SHOULD DISCLOSE THE IDENTITIES OF ALLEGED CRIME VICTIMS
}

\author{
SARAH Henderson HutT*
}

\section{INTRODUCTION}

Recent events have made crime victims the subject of intense public attention and debate. The New York Times's controversial decision on April 16, 1991, to publish the name of an alleged rape victim, caused a public outrage, ${ }^{1}$ prompting the state legislature to seek new ways to restrict public access to the identities of alleged crime victims. ${ }^{2}$ On July 19, the New York State Legislature passed a bill that requires police, prosecutors, and court officials to keep the identities of victims of sexual offenses confidential. ${ }^{3}$ The bill provides that "[n]o report, paper, picture, photograph, court file or other documents ... which identifies such a victim shall be made available for public inspection"; disclosure of the

- The author thanks David Grahm for providing her with the topic of this Note.

1. See, e.g., Rita Ciolli, Editors Debate Use of Women's Name, NEWSDAY, Apr. 18, 1991, at A7 (reporting that editors of the Los Angeles Times, Cable News Network, the Washington Post, USA Today, ABC News, the New York Daily News, and the New York Post defended their policy of shielding rape victims froin publicity and criticized news organizations that published and broadcasted the victim's name); Susan Estrich, The Real Palm Beach Story, N.Y. TiMES, Apr. 18, 1991, at A25 ("The Times's explanation for its decision to publish her name was that NBC News had done it the night before. My 5-year-old nephew couldn't have put it better."); William Glaberson, Media Memo: Times Article Naming Rape Accuser Ignites Debate on Journalistic Values, N.Y. Times, Apr. 26, 1991, at A14 (stating that the debate over the Times's decision to publish the rape victim's name has brought "scathing" criticism from other publications and from the Times's own editors and reporters).

On May 9, Palm Beach County filed charges against the Globe for violating Florida law by publishing the rape victim's name. Larry Tye, Paper Charged for Naming Woman in Florida Case, Boston Globe, May 10, 1991, at A12.

2. See John Riley, Cuomo Gets Bill to Bar Rape IDs, NewsDaY, July 19, 1991, at A19. Throughout this Note the word "victim" refers to alleged victim.

3. Act of July 1, 1991, ch. 251, 1991 Sess. Law News of N.Y. (McKinney) (to be codified at N.Y. Civ. Rughts LaW $\S \S 50-b$ to $-c$ ). The bill in no way prevents public presence at criminal proceedings. See Riley, supra note 2, at A19. 
identity can result in civil liabilities. ${ }^{4}$ Later that montl1, New York Governor Mario Cuomo signed the bill. ${ }^{5}$

Two other states havc recently restricted public disclosure of a rape victim's identity. In September of 1991, Alaska passed a bill that deems the name of a victim of a sexual offense not to be a matter of public record and that provides for the use of the victim's initials in all transcripts of otherwise open proceedings. 6 Louisiana amended its public records law to exempt from public disclosure all law enforcement records that reveal the identity of a victim of a sexual offense.?

As these state laws demonstrate, the inost recent attempts to protect rape victims' identities lave not been aimed at punishing the press who decide to publish a victim's name, but rather have been aimed at cutting off public access to identifying information that typically appears in complaints, imcident reports, and transcripts of criminal proceedings. Traditionally, the government has not restricted access to the identities of persons appearing in these records unless disclosure of that information would place the victim in pliysical danger or would impede an ongoimg criminal investigation. Now, the government is restricting access to victims' identities for the primary reason of protecting tlie victim's privacy. ${ }^{8}$ This Note examines whether such restrictions are an impermissible infringeinent on the public's First Amendment right of access to information about the criminal justice system. 9

This Note examines the legal issues that arise out of government restrictions on public access in two hypothetical situations. The first situation occurs when the police redact a victim's identity in the complamts and incident reports that they routinely release to the public. In this situation, restriction occurs at the investigative or law enforcement stage

4. Act of July 1, 1991, ch. 251, 1991 Sess. Law News of N.Y. (McKinney) (to be codified at N.Y. CIV. RIGHTS LAW § 50-b(1)).

5. See Globe Charged for Identifying Rape Victim, NEws MEDIA \& THE LAw, Summer 1991, at $24,25$.

6. See Victims' Rights Act of 1991, ch. 57, §13, 1991 Alaska Sess. Law Service (West) (to be codified at ALASKa STAT. $\$ 12.61 .140$ ). Like the New York bill, the Alaska bill does not limit public presence at criminal proceedings. See id. (to be codified at ALASKa STAT. § 12.61.150).

7. See Act of June 25, 1991, Act No. 86, $\S 1,1991$ La. Sess. Law Serv. (West) (to be codified at LA. REv. STAT. ANN. § 44.3(A)(4)(d)).

8. This Note does not extend its argument to situations in which the governmeut protects a victim's identity for the purposes of guarding against further bodily injury or threats of injury.

9. This Note does not address the issue of whether a government can prohibit the publication of a victim's identity or punish news nedia that publish a victim's identity. This Note also does not restrict itself to discussing rape victims or the victims of sexual assault, although rape victims will merit extra discussion throughout the Note because inuch of the public controversy and inany of the protective statutes at issue center on rape victims. The geuder-neutral pronoun "Iie" will refer to the alleged victin throughout the Note to remind the reader that victims-even victins of sexual assault-are frequently inale. 
of. a criminal matter. The second situation occurs when a court employs a pseudonym to designate a victim, or otherwise prohibits access to the victim's name, in all proceedings and records generated by a criminal mcident. This scenario occurs during the pre-trial and trial stages of a criminal matter.

Part I of this Note describes the framework of legal analysis established by the Supreme Court in Richmond Newspapers, Inc. v. Virginia, ${ }^{10}$ Globe Newspaper Co. v. Superior Court, ${ }^{11}$ and the Press-Enterprise cases. ${ }^{12}$ This line of cases established a two-part test-the Globe testthat measures whether the public's right of access attaches to a particular proceeding or piece of information, and if so, whether the government has asserted a reason sufficient to restrict that right. Additionally, Part I briefly surveys the findings of courts that have applied the Globe test to various proceedings and information connected with the criminal justice system.

Part II applies right of access analysis to the hypothetical situation in which the government withholds a victim's identity at the investigative stage of a criminal matter. Based on a historical and functional analysis of public access to a victim's identity, Part II shows that the public has a constitutionally protected right of access to a victim's identity, and that this information is presumptively open to the public unless the government asserts a compelling reason for denying access. Part II also argues that the government shonld not exempt a victim's identity from disclosure under freedom of infornation requests, nor should it exclude the victim's identity from complaints or incident reports, when the sole justification is to protect an adult victim's privacy. ${ }^{13}$ Protecting a victim's privacy at the investigative stage is not sonnd public policy because it is unclear that this policy benefits victims and because it jeopardizes the integrity of the criminal justice system.

Part III applies right of access analysis to the hypothetical situation in which a government restricts access to a victim's identity at the pretrial and trial stages of a criminal matter. Part III reviews First and Sixth Amendinent cases ${ }^{14}$ in which the public has challenged restrictions on access to information revealed at trial. Part III concludes that a restriction on access to a victim's identity is a drastic restraint on public

10. 448 U.S. 555 (1980).

11. 457 U.S. 596 (1982).

12. Press-Enterprise Co. v. Superior Court (Press-Enterprise I), 464 U.S. 501 (1984); PressEnterprise Co. v. Superior Court (Press-Enterprise II), 478 U.S. 1 (1986).

13. This Note does not address statutes that restrict access to the identity of a minor victim.

14. Because there are no cases directly on point, Part III draws upon Sixth Amendment jurisprudence for comparison. See infra note 198 (explaining the congruence between First and Sixth Amendment cases). 
access that is only justified when the life of a participant in the trial is at stake, or when the fairness of the entire proceeding would be jeopardized by access. It also argues that by atteinpting to protect the privacy interests of a victim over the public's interest in overseeing criminal proceedings, the state would actually be undermining the victim's own interest.

\section{The First Amendment Right of ACCess AND the GLOBE TEST}

\section{A. The First Amendment Right of Access}

The First Amendment right of access was announced by seven Supreine Court justices in Richmond Newspapers, Inc. v. Virginia ${ }^{15}$ in which the Court invalidated a trial judge's decision to close a criminal trial to the public. ${ }^{16}$ In the plurality opinion, Chief Justice Burger concluded that "a presumption of opeuness inheres in the very nature of a criminal trial under our systein of justice,"17 that "the right to attend criminal trials is imphicit in the guarantees of the First Amendment,"18 and that "[a]bsent an overriding interest articulated in findimgs, the trial of a criminal case inust be open to the public."19 The Richmond Newspapers Court did not, however, announce a clear standard for assessing how the state could rebut the presumption of opermess that attaches to a criminal trial. ${ }^{20}$

Relying on Richmond Newspapers, a majority of the Supreine Court in Globe Newspaper Co. v. Superior Court ${ }^{21}$ invalidated a Massachusetts statute that mandatorily excluded the public froin all sex-offense trials during the testimony of a minor victim. The Globe majority affirmed the

15. 448 U.S. 555 (1980). Previously, in Gannett Co. v. DePasquale, 443 U.S. 368 (1979), the Court held that the public's right of access does not derive from the Sixth Amendmeut "public trial" provision because that guarantee is created for the benefit of the defendant. The Court reasoned that the public has certain Sixth Amendment interests that are distinct from the defendant's-an interest in the swift and fair exeeution of justice and in participating in the trial as jurors-but that the public's interest in the administration of justice is fully protected by the actual parties to the litigation. See id. at 383-84.

16. See Richmond Newspapers, 448 U.S. at 581.

17. Id. at 573 .

18. Id. at 580 .

19. Id. at 581 (footnotes omitted).

20. The plurality wrote that the First Amendment rights of the public and representatives of the press are not absolute: "[A] trial judge [may], in the interest of the fair administration of justice, impose reasonable limitations on access to a trial." Id. at $581 \mathrm{n} .18$ (emphasis added). In his concurring opinion, Justice Stevens asserted that "the Court unequivocally holds tlat an arbitrary interference with access to important information is an abridgment of the ... First Ameudment." Id. at 583 (Stevens, J., concurring) (emphasis added).

21. 457 U.S. 596 (1982). 
conclusion in Richmond Newspapers that the First Amendment guarantees a right of public access to criminal trials and established a standard for determining the circumstances under which the right may be limited. 22

The Globe Court indicated that the public right of access should be construed broadly because it supports one of the fundamental purposes of the First Amendment, the " "free discussion of governmental affairs," "23 by ensuring that the public's discussion of its government "is an informed one."24 The Supreme Court thus perceived the First Amendinent right of access to be a broad right, apphicable not only to the criminal justice systein but also to the loosely-defined category of "governmental affairs." 25 To suit the broad reach of the public's right of access, the Globe Court estabhished a flexible, two-part framework for determining the government affairs to which the right attaches, and the circumstances under which those affairs can be closed to the public. ${ }^{26}$

The first part of the Globe test examines whether a right of access adheres to a particular process and thus whether that process is presumptively open to the public. Two factors are relevant to this imquiry: first, whether there is a historical tradition of public access to that proceeding; and second, whether there is a functional value associated with opening that proceeding to the public. ${ }^{27}$

The second part of the Globe test ineasures whether the government has asserted an interest sufficiently compelling to warrant closure. ${ }^{28}$ Significantly, the Court stated that the right of access to criminal trials is "of constitutional stature," but "not absolute." 29 Thus, in "limited" circumstances the press and public can be excluded from a criminal trial. ${ }^{30}$ The Globe Court ruled that if the government wislies to deny public access to a criminal proceeding to which the right applies, "it inust be shown that the derial is necessitated by a compelling governmental imterest, and is

22. See id. at 605 .

23. Id. at 604 (quoting Mills v. Alabama, 384 U.S. 214, 218 (1966)).

24. Id. at 605 .

25. In the same vein, Justice Steveus wrote in his concurrence to Press-Enterprise I, 464 U.S. 501 (1984), that "the distinction between trials and other official proceedings is not necessarily dispositive, or even important, in evaluating the First Amendinent issues." Id. at 516 (Stevens, J., concurring). Instead, First Amendment inquiries focus on the " "historical backdrop" " against which the First Amendment was enacted, and whether the right of access would make a "positive contribution to [the American] process of self-governance." Id. at 517-18 (quoting Press-Enterprise I, 464 U.S. at 509 n.8).

26. See id. at 605-07.

27. See Globe, 457 U.S. at $605-06$. The Court later refers to these factors as "considerations of experience and logic." Press-Enterprise II, 478 U.S. 1, 9 (1986).

28. See Globe, 457 U.S. at 607.

29. Id. at 606 .

30. Id. 
narrowly tailored to serve that interest,"31 and is supported by specific findings that the coinpelling interest would be jeopardized by public disclosure. ${ }^{32}$

In the criminal justice context, the Globe test has been used to ineasure the pubhc's right of access to government information at many different stages of the system. ${ }^{33}$ The Globe test would be used to measure whether a public right of access attaches to a victim's identity at the investigative stage of a criminal inatter, 34 and whether the government can conceal a victim's identity at the pre-trial and trial stages of a matter.

\section{B. Previous Applications of the Globe Test}

The first part of the Globe test rehes on two factors to measure whether the right of access attaches to a criminal proceeding. The first factor focuses on whether there is a tradition of accessibility; the second factor focuses on whether public access is significant to the proper functioning of the process in question. ${ }^{35}$ The Globe Court noted that criminal trials have been presumptively open since the Constitution was adopted, and furthermore that openness enhances functional values such as fostering an appearance of fairness, heightening respect for the judicial process, and performing a check on the criminal justice process-tlie last function being an "essential coinponent in our structure of self-government."36 State and federal courts lave examined these factors to determine whether a right of access exists in proceedings ranging from plea hearings to warrant issuings.

31. Id. at 607 .

32. See id. at 609 .

33. See infra text accompanying notes 37-43.

34. In Press-Enterprise II, 478 U.S. 1 (1986), the Supreme Court reiterated its broad-reaching approach by commeuting that the public's right of access does not depend on the name of the proceeding, but rather depeuds on the two factors of tradition and function. See id. at 8; see also United States v. Doherty, 675 F. Supp. 719 (D. Mass. 1987) (holding that it is imconsequential whether postverdict interviews are part of the trial for purposes of right of access analysis).

The broad applicability of the Globe test is partly explained by the breadth of the fuuctional analysis conducted in the first part of the test. In Globe, the najority noted that public access to criminal trials "plays a particularly significant role in the functioning of the judicial process and the government as a whole." 457 U.S. at 606 . The Court's analysis thus was not confined to the functioning of the criminal justice system, but also considered how pubhic access enhanced the entire system of self-government.

35. See Globe, 457 U.S. at 605-06.

36. Id. 
A presumption of openness has been found in almost all proceedings that are arguably part of the pre-trial or trial stages. ${ }^{37}$ Trials are presumptively open, ${ }^{38}$ as are juror voir dire, ${ }^{39}$ preliminary hearings, ${ }^{40}$ suppression hearings, ${ }^{41}$ plea hearings, ${ }^{42}$ and change of venue hearings. ${ }^{43}$ The scope of the right of access extends to information revealed at the hearing to which the right attaches, including information contained in documents submitted to the court in the course of the proceeding. 44 In juvenile matters, however, state courts have tended to deny the public a presumption of openness. 45

The first part of the Globe test has produced contrary results in one context: Three federal circuit courts have sphit over the public's right of access to affidavits submitted in support of a warrant apphication. ${ }^{46}$ The Court of Appeals for the Eighth Circuit found a historical tradition of access to such documents because warrant apphications are typically filed with the clerk of court after the warrant proceeding and thus become part of the public record; furthermore, public access to the affidavits

37. But see United States v. Edwards, 823 F.2d 111, 117 (5th Cir. 1987) (holding that a right of access does not attach to midtrial hearings investigating possible juror misconduct).

38. See Globe, 457 U.S. at 605 (quoting Richmond Newspapers, Inc. v. Virginia, 448 U.S. 555, 569 (1980)).

39. See Press-Enterprise I, 464 U.S. 501, 505-10 (1984); In re Dallas Morning News Co., 916 F.2d 205, 206 (5th Cir. 1990); Gannett Co. v. State, 571 A.2d 735, 741 (Del. 1990).

40. See Press-Enterprise II, 478 U.S. 1, 13 (1986).

41. See In re New York Times Co., 828 F.2d 110, 113 (2d Cir. 1987).

42. See In re Washington Post Co., 807 F.2d 383, 389 (4th Cir. 1986).

43. See In re Charlotte Observer, 882 F.2d 850, 853 (4th Cir. 1989).

44. See Washington Post Co. v. Robinson, 935 F.2d 282, 287 (D.C. Cir. 1991) (right attaches to plea agreenient); John Does I-V v. Pulitzer Publishing Co., 895 F.2d 460, 467 (8tl Cir. 1990) (right attaches to identities of suspects for whoin search warrants (but no indictnents) have issued); New York Times, 828 F.2d at 114 (right attaches to notions at a suppression hearing); Washington Post, 807 F.2d at 389-90 (right attacles to documents filed in plea and sentencing hearings); United States v. Smith, 776 F.2d 1104, 1111 (3d Cir. 1985) (right attaches to names on bill of particulars); Associated Press v. United States Dist. Court, 705 F.2d 1143, 1145 (9th Cir. 1983) (right attaches to documents filed in pretrial proceedings); United States v. Doherty, 675 F. Supp. 719, 723 (D. Mass. 1987) (right attacles to jurors' names a reasonable time after verdict is delivered); Copley Press, Inc. v. San Diego County Superior Court, 278 Cal. Rptr. 443, 448 (Ct. App. 1991) (right attaches to questionnaire conipleted by venirepersons who are ultimately called to the jury box).

45. See, e.g., San Bernardino Connty Dep't of Pub. Social Servs. v. Superior Court (Sun Newspaper), 283 Cal. Rptr. 332 (Ct. App. 1991) (denying right of access in jnvenile dependency hearings); Florida Publishing Co. v. Morgan, 322 S.E.2d 233 (Ga. 1984) (denying right of access in delinquency, deprivation, and unruliness learings); In re Minor, 563 N.E.2d 1069 (Ill. App. Ct. 1990) (denying right of access in liearing on jnvenile plysical and sexual abuse); In re T.R., 556 N.E.2d 439 (Ohio 1990) (denying right of access in juvenile proceedings to determine if child is abused, negleeted, or dependent, or to determine custody); Associated Press v. Bradshaw, 410 N.W.2d 577 (S.D. 1987) (denying right of access in juvenile proceedings); In re N.H.B., 769 P.2d 844 (Utah Ct. App. 1989) (same). But see New Jersey Div. of Youth \& Family Servs. v. J.B., 576 A.2d 261 (N.J. 1990) (allowing press to attend pretrial hearing in juvenile nuatter).

46. See Baltiniore Sun Co. v. Goetz, 886 F.2d 60 (4th Cir. 1989); Tines Mirror Co. v. United States, 873 F.2d 1210 (9th Cir. 1989); In re Search Warrant (Gunn), 855 F.2d 569 (8th Cir. 1988). 
would promote the public's understanding of the criminal justice system and act as a check on prosecutorial abuse. ${ }^{47}$ Reaching the opposite result, the Fourtl and Ninth Circuits held that there is no right of access because warrant proceedings-even if they later become part of the public record-are traditionally closed to the public, and because the functional values of public access are outweighed by the danger that public access to such affidavits will impede the investigation of crime. ${ }^{48}$ These cases reveal that the first part of the Globe test is susceptible to soine uncertainty im application, especially when the information in question is not revealed at the pre-trial or trial stage of the matter but is revealed at the investigative stage.

After a court finds that a presumption of opeuness adheres to a proceeding or to a document associated with that proceeding, Globe analysis requires the court to consider whether the party wishing to restrict access has asserted a coinpelling interest, ${ }^{49}$ whether the restriction was narrowly tailored to serve that interest, and wliether the trial judge made "specific, on the record findings" that the interest asserted would be jeopardized by public disclosure. ${ }^{50}$

Cases show that the "compelling interest" aspect of the test is a relatively flexible threshold, but that atteinpts to restrict public access have foundered on the second requirement-that closure be "narrowly tailored" to accomplish its stated purpose. In Globe, for example, the Supreme Court invalidated a Massacliusetts statute that mandatorily excluded the public from all sex-offense trials during the testimony of a minor victim because it permitted a trial judge to exclude the public witlout making specific findings of need. The Court found that the state had a compelling interest in "safeguarding the pliysical and psycliological well-being of a minor," but that the mandatory exclusion of the press during the minor's testimony was not a narrowly tailored means of accommodating that interest. ${ }^{51}$ Instead, a trial judge must base his decision to close a proceeding on specific factors such as "the minor victim's age,

47. See Gunn, 855 F.2d at 572-73.

48. See Baltimore Sun, 886 F.2d at 64-65; Times Mirror, 873 F.2d at 1213-16.

49. The Supreme Court has changed the wording, but not the meaning, of Globe's "compelling interest" test. In Press-Enterprise I, 464 U.S. 501 (1984), the Court wrote that "[t] the presumption of openness may be overcome only by an overriding interest based on findings that closure is essential to preserve higher values and is narrowly tailored to serve that interest." Id. at 510; see also PressEnterprise II, 478 U.S. 1, 13-14 (1986) (quoting Press-Enterprise I, 464 U.S. at 510). Because there is no indication that these different phrases have different meanings, this Note will use the more graceful Globe terminology. See Baltimore Sun, 886 F.2d at 64-65 (Fourth Circuit using Globe terminology and Press-Enterprise $I$ termmology interchangeably).

50. Press-Enterprise II, 478 U.S. at 13-14; accord Globe Newspaper Co. v. Superior Court, 457 U.S. 596, 609 (1982).

51. Globe, 457 U.S. at $607-08$. 
psychological maturity and understanding, the nature of the crime, the desires of the victim, and the interests of parents and relatives."52

Interests that courts have deeined compelling include protecting a defendant's right to a fair trial, ${ }^{53}$ protecting minor victims of sex crimes, ${ }^{54}$ and preserving the impartiality and viability of a jury. ${ }^{55}$ Courts have also held that certain interests justify restrictions on the public's access to identifying information such as the names of suspects for whom search warrants but no mdictinents have issued, or the naines of unindicted but suspected co-conspirators. ${ }^{56}$ In each case, the state had to make substantial showings that the interest at stake would be jeopardized by public disclosure; none of the above imterests are per se compelling. ${ }^{57}$

Finally, the means of restriction that the government employs inust be as narrow as possible to protect the specific imterest against the likely harm. Courts have approved a range of methods for restricting access, including the delayed release of court records, the release of redacted

52. Id. at 608 (footnotes omitted).

53. See, eg., Copley Press, Inc. v. San Diego County Superior Court, 278 Cal. Rptr. 443 (Ct. App. 1991) (holding that defendant's right to fair trial justified delayed release of questionnaires given to venirepersons in capital case); Cowles Publishing Co. v. Magistrate Court, 800 P.2d 640, 647 (Idaho 1990) (determining that defendant's right to fair trial justified exclusion of public from preliminary hearing). But see In re Charlotte Observer, 882 F.2d 850 (4th Cir. 1989) (holding that fair trial right did not justify closing defendant's change of venue proceeding).

54. See, e.g., Globe, 457 U.S. at 607-08; In re V.V. Publishing Corp., 577 A.2d 412 (N.J. 1990) (deciding that state interest in protecting minor victims of sex crimes justifies court order permitting full media access conditioned on media's promise not to make public victinus' identities).

55. See, e.g., United States v. Edwards, 823 F.2d 111 (5th Cir. 1987) (holding that interest in preserving the jury justified excluding public from mid-trial hearings on possible juror misconduct); Gannett Co. v. State, 571 A.2d 735 (Del. 1990) (finding that interest in maintaining impartiality of jurors justified anonymous jury).

56. See, eg., John Does I-V v. Pulitzer Publishing Co., 895 F.2d 460, 466 (8th Cir. 1990) (holding that privacy interests justify denying access to names); United States v. Sunith, 776 F.2d 1104, 1113-14 (3d Cir. 1985) (same); see also Press-Enterprise I, 464 U.S. 501, 512 (1984) (allowing privacy interests of some venirepersons in a rape trial to prevail over right of access); In re New York Times Co., 828 F.2d 110, 116 (2d Cir. '1987) (holding privacy interests in motion to suppress evidence obtained fron wiretap paramount to right of access).

57. For example, the state's interest in preserving the secrecy of grand jury proceedings and in protecting an ongoing criminal investigation were found to be insufficient justifications for sealing a plea agreement in a nuatter involving the Mayor of the District of Columbia. See Washington Post v. Robinsou, 935 F.2d 282, 291-92 (D.C. Cir. 1991). The D.C. Circuit found that the plea agreement made no reference to grand jury proceedings, or even to the Mayor. See id; see also In re Charlotte Observer, 882 F.2d 850, 856 (4th Cir. 1989) (finding that defendant's fair trial right did not justify closing defendant's change of venue proceeding); Cable News Network, Inc. v. United States, 824 F.2d 1046 (D.C. Cir. 1987) (judging closure of voir dire to be inappropriate because no specific findings were made that public interrogation would touch on deeply personal matters); United States v. Peters, 754 F.2d 753, 760 (7th Cir. 1985) (holding that judge who was "a little bit chagrined", id. at 756 , at seeing voir dire answers reprinted in the paper could not close voir dire absent specific findings); New Jersey Div. of Youth \& Family Servs. v. J.B., 576 A.2d 261, 270 (N.J. 1990) (holding that state did not have a compelling interest in excluding public from juvenile proceeding when proceeding did not concern possible sexual or pliysical abuse). 
transcripts, partial closure of particular hearings during certain testimony, or even complete closure of a hearing. ${ }^{58}$

\section{Application of the Globe Test to the InVestigative Stage of a CRiminal MatTer}

At the imvestigative stage of a criminal matter, ${ }^{59}$ the public usually has access to complaints and incident reports soon after a criminal incident has been reported. These documents contain basic factual information, including a description of the incident and its date, time, location, any arrests, and the identity of the victim. ${ }^{60}$ In some states and in soine cases, the pohice will black out the victim's identity and refuse to release that information to the public, even though it is willing to release the rest of the information. ${ }^{61}$ This practice of redacting a victim's identity is routine procedure in soine states, but it also represents a significant infringement on the public's access to information concerning criminal matters.

This Part examines whether a First Amendinent riglit of access attaches to a victim's identity at the investigative stage of a criminal inatter by applying the two-part Globe test. Part II argues that both factors of the first part of the test-historical tradition of access and functional value of access-support a public right of access to a victim's identity at the investigative stage, and furthermore that the government does not have a compelling interest, even in rape cases, in restricting public access to this information.

58. See, e.g., Press-Enterprise I, 464 U.S. at 512 (suggesting appropriate ways of restricting access); In re Dallas Morning News Co., 916 F.2d 205, 206 (5th Cir. 1990) (allowing prospective jurors to make specific request for private voir dire questioning with judge); United States v. Doherty, 675 F. Supp. 719, 723-24 (D. Mass. 1987) (coucluding that the public and the press have a right of access to jurors' names and addresses at some reasonable time after a verdict is delivered but that court inay delay release to prevent harassment).

59. "Investigative stage" refers to the time after the complaint or reporting of a criminal act until the time when the pretrial right of access attaches.

60. See Police Records: $A$ Guide to Effective Access in the 50 States and D.C., NEwS MEDIA \& L., Sunmer 1987, at 10-11 (Supp.) [hereinafter Access Guide].

61. See, e.g., IND. CODE ANN. § 5-14-3-5(c) (Burns 1987) ("If an agency maimtains a daily log or record that lists ... complaints, the following information shall be made available for inspection and copying: ... the name and age of any victim, unless the victim is a victim of a [sex crime]."); Fox Butterfield, Lawyers in Case of Kennedy Nephew Clash over Conduct of Investigators, N.Y. TIMEs, April 13, 1991, § 1, at 6 ("The name of the woman was blacked out in both police reports. The wounan's name has not been published in American newspapers, though it is widely known in Palm Beach."); see infra notes 93-96 and accoinpanying text (discussing state statutes that release incident reports but not the viction's name). 


\section{A. The First Part of the Globe Test: The Public's Right of Access to a Victim's Identity at the Investigative Stage of a Criminal Matter}

The first part of the Globe test determines whether the public has a right of access to a criminal proceeding or information revealed therein. ${ }^{62}$ Although the Supreine Court has not apphed the Globe test to information concerning the investigative stage of a criminal matter, the federal courts of appeals have apphied the test to measure whether the public has a right of access to investigative information such as names histed on a bill of particulars, ${ }^{63}$ names on search warrants, ${ }^{64}$ and affidavits submitted in support of a search warrant. ${ }^{65}$ Apphied to the hypothetical situation in which a state governinent has decided to prohibit disclosure of a victim's identity on all investigative documents, including the complamt and incident report, the Globe factors reveal that the public has a right of access to such information, and that the victim's identity is presumptively pubhic information unless the governinent can assert a coinpelling interest in kecping it confidential.

1. The First Globe Factor: Historical Tradition of Access. The Supreme Court relies upon a broad spectrum of historical information, ranging froin the custoins of early common law to modern statutory and case law, when it considers whether there is a historical tradition of access to a proceeding. ${ }^{66}$ The guiding principle behind its historical analysis is a consideration of the "historical backdrop" agamst which the First

62. See Globe Newspaper Co. v. Superior Court, 457 U.S. 596, 605 (1982).

63. See United States v. Smith, 776 F.2d 1104, 1114 (3d Cir. 1985).

64. See John Does I-V v. Pulitzer Publishing Co., 895 F.2d 460, 462 (8th Cir. 1990).

65. See Baltimore Sun Co. v. Goetz, 886 F.2d 60, 64-65 (4th Cir. 1989); Tinies Mirror Co. v. United States, 873 F.2d 1210, 1213-16 (9th Cir. 1989); In re Search Warrant (Gunn), 855 F.2d 569, 572-73 (8th Cir. 1988). See supra text accompanying notes 46-48 (discussing the circuit split over whether a public right of access attaches to such affidavits).

66. In Press-Enterprise II, 478 U.S. 1 (1986), for example, the Court examined both modern and older traditions of access to preliminary hearings. The Court analogized California's proceedings to the probable cause hearing in Aaron Burr's treason trial, which was held in the Virginia House of Delegates to accommodate the crowds. See id. at 10-11. On the other hand, the Court noted that niany states curreutly allow preliminary hearings to be closed to the public on the motion of the accused for cause shown. See id. at $11 \&$ n.4. Although the historical tradition of openness for a preliminary hearing was nore tenuous than was the tradition for voir dire, the Court nevertheless found that open hearings had been accorded " 'the favorable judgment of experience." " Id. at 11 (quoting Globe, 457 U.S. at 605). 
Amendment was enacted ${ }^{67}$ - the tradition of access at the time of constitutional ratification. ${ }^{68}$ A historical examination of public access to a crime victim's identity reveals a mixed tradition. The common law tradition of criminal justice presumed that a victim's identity would be a matter of community knowledge; however, the contemporary criminal justicc system and various public records statutes show that the government currently enjoys broad discretion over the information it releases at the investigative stage of a criminal matter.

The victim and the community's role in the Anglo-American criminal justice systein has evolved, froin the time of Ethelbert $\mathrm{I}^{69}$ to the present, from one of intimate involvement with the process of investigating, apprehending, and prosecuting an offender to one of virtual absence froin every stage of the process. In England, commumity involvement was vital to the investigation of criminal incidents and the apprehension of suspected offenders. In the later imiddle ages, when victims were responsible for prosecuting their own cases, victims rehed on their neighbors to help them investigate crimes, detect the perpetrator, and apprehend him by raising a "hue and cry."70 Significantly, the community did not learn about the crime froin official sources; instead, officials learned about the crime froin the commumity. ${ }^{71}$ In seventeenth-century England, investigating, detecting, and apprehending a criminal was still a inatter of commumity rather than official responsibility. ${ }^{72}$

In colonial America, just before the ratification of the First Amendinent, the victim and community were similarly mvolved in the detection and prosecution of criminal justice. The burden and costs of arresting an offender, investigating the crime, and retaining a prosecuting attorney

67. See Press-Enterprise I, 464 U.S. 501, 509 n.8 (1980); id. at 517 (Stevens, J., concurring); see also Richmond Newspapers, Inc. v. Virginia, 448 U.S. 555, 575 (1980) ("The Bill of Rights was enacted against the backdrop of the long history of trials being presumptively open.").

68. See Globe, 457 U.S. at 605 (" "[A]t the time when our organic laws were adopted, criminal trials both here and in England had long been presumptively open.' ") (quoting Richmond Newspapers, 448 U.S. at 569) (brackets in original). In Press-Enterprise I, the Court conducted an extensive historical survey to conclude that the tradition of public juror selection began in the sixteenth century and that the "presumptive openness" of the voir dire was carried over into proceedings in colonial America. See 464 U.S. at 507-08.

69. King of Kent from 560 until 616 A.D., Ethelbert (or Aethelbert) issued the first written code of Anglo-Saxon laws. I ENCYClOPAEDiA BRITTANICA Aethelbert 230 (1965).

70. Edward A. Ziegenhagen, Victims, Crime and Social Control 65 (1977).

71. See id. ("Whatever information was communicated apparently came to the attention of officials via community consensus.").

72. Cynthia B. Herrup, The Common Peace: Participation and the Criminal Law IN SEVENTEENTH-CENTURY ENGLAND 68-69, 72 (1987). 
rested entirely on the victim. ${ }^{73}$ Given the responsibilities of victim and community in carrying out the criminal law, a victim could not have reinained anonymous and also have prosecuted his case. The community had to know the victim's identity to fulfill its role in the systen.

Even though early legal history shows a strong tradition of commumity access, more recent history shows that the community no longer needs access to a victim's identity for the criminal justice system to operate. The role of the victim and the community in the American criminal justice system has steadily declined since the War of Independence. ${ }^{74}$ Factors contributing to this decline include Cesare Beccaria's influential Essay on Crimes and Punishment, ${ }^{75}$ nineteenth-century reforms in the correction system, the creation of public police forces, and the rise of the public prosecutor's office. ${ }^{76}$ In the modern criminal justice systen, the victim plays a minimal role that primarily involves reporting a crime to the pohice. Once the police arrest a suspect, the victim adopts the legal status of a witness. ${ }^{77}$ A victim cannot prosecute under the criminal laws; for serious crimes, the decision to prosecute must be made by a prosecutor. ${ }^{78}$ The inodern systen thus rehes on the state to investigate, apprehend, and prosecute criminal offenders. Because the victim no longer rehes on himself or on community involventent to vindicate his injury,

73. ZIEGENHAGEN, supra note 70, at 65 ; William F. McDonald, Towards a Bicentennial Revolution in Criminal Justice: The Return of the Victim, 13 AM. CRIM. L. REV. 649, 651-54 (1976).

74. ZiEgEnHAGEN, supra note 70 , at 67.

75. Cesare Beccaria, Essay on Crimes and Punishment (1764).

Beccaria argued that criminal acts are an injury to the state and thus should be vindicated by the state, not by individuals. He also argued that punishment should be imposed for deterrent purposes and for the offender to repay his debt to society, not for the offender to inake reparations to the injured individual. For discussions of the implications of Beccaria's theories, see JoHN HAGAN, Victims Before the LaW: The ORganizational Domination of Criminal LaW 11 (1983); ZIEGENHAGEN, supra note 70, at 68; McDonald, supra note 73, at 654-56.

76. See McDonald, supra note 73, at 656-68.

77. ZiEgenhaGeN, supra note 70, at 76; Abraham S. Goldstein, Defining the Role of the Victim in Criminal Prosecution, 52 MIss. L.J. 515, 548 (1982). Because of the presumption of innocence that attaches to the defendant, a victim is only a presumptive or alleged victin until the defendant has been convicted. ZIEGENHAGEN, supra note 70, at 79.

78. Sarah N. Welling, Victims in the Criminal Process: A Utilitarian Analysis of Victim Participation in the Charging Decision, 30 ARIZ. L. REV. 85, 105-08 (1988). In soine jurisdictions, however, a court will issue a misdemeanor charge based solely on a citizen coinplaint. 2 WAYNE R. LaFave \& Jerold H. Israel, Criminal Procedure $\S 13.1$ (1984). Commentators generally agree, however, that the victim shonld not have a formal role in the charging procedure. See, e.g., Goldstein, supra note 77, at $557 \mathrm{n} .88$ (suggesting that victims be included before conviction in hearings on disnissals, charge reductions, and guilty pleas, and after conviction on restitution and sentencing issues, but not at the imitial charging stage); Welling, supra, at 116 (arguing that victin should be allowed to give his opinion on the charge but should not have the right to determine the substance of the charge). 
the community has no need to know the victim's identity for the criminal system to operate.

As the community's functional role has declined, the media have, to a large extent, taken over the role that the community once played in the investigation of criminal incidents. Although the media do not directly aid either the victim or the police, they do play an essential role in overseeing the investigative process and in conducting independent investigations into criminal matters. ${ }^{79}$ But the role of the community has not wholly disappeared in the criminal process. Although meinbers of the general public no longer play an active role in the investigation of a crime, the identity of a crime victim is-as a matter of historical phenomenon-information in which the public tends to be interested, and to which sinall communities typically have access through unofficial sources. ${ }^{80}$

The current practice in public records law permits federal and state governments to assume broad discretion over the release of law enforcement and investigative records. The Supreme Court has never directly ruled on the issue of whether a government may withhold a crime victim's identity from the public, but it has indicated that the government

79. See Richmond Newspapers, Inc. v. Virginia, 448 U.S. 555, 572-73 (1980) ("Instead of acquiring information about trials by firsthand observation or by word of mouth from those who attended, people now acquire it chiefly through the primt and electromic media."); LyLE W. Denniston, The Reporter and the LAW: Techniques of Covering the CoUrTs, at $x i x-x x$, 4, 9 (1980); infra notes 113-21 and accompanying text (discussing the functional role of the media).

80. Obviously this assertion will be more true in small towns than in large cities. If community is understood in a more general sense- to imdicate a place of employment, or a school, or a church, for example-then the assertion is applicable even in a large city. Even when police policy is not to release victims' names, gossip and strect talk usually provide interested members of the community with the victim's identity. To illustrate, the identity of the alleged victim of the William Kennedy Smith rape was widely known within three days in Palm Beach, Florida, a city of 870,800 residents. RaNd McNally, 1991 Commercial ATLas and Marketing Guide 292 (estimated current population). Because Florida law prevents the disclosure or publication of rape victims' names, the community must have gamed access to the victim's name through nnofficial sources who "leaked" the information. John A. Farrell \& Sally Jacobs, Pace of Florida Rape Probe Faulted, Boston GLoBE, Apr. 5, 1991, at A1 (The rape was reported on a Saturday afternoon. "Though details concerning the attack have been guarded by the police, the name of the woman found its way to reporters as early as Tuesday morning. By Tuesday night, her home had been located and the first neighbors had been interviewed. ... Though it is against Florida law to publish a rape victim's name, the woman found herself besieged in her home, and the talk of her community."); see also Fox Butterfield, Lawyers in Case of Kennedy Nephew Clash over Conduct of Investigators, N.Y. TIMEs, Apr. 13, 1991, §1, at 6 ("The name of the wonsan was blacked out in both police reports. The woman's name has not been published in American newspapers, though it is widely known in Palm Beach."); FLA. StaT. ch. 119.07(3)(h) (Supp. 1991). 
can withhold records and information pertaining to criminal investigations. The Court's decisions show, for example, that there is no historical basis for public access to the investigative information gathered in grand jury proceedings. ${ }^{81}$

Were the public to request access to investigative or law enforceinent records containing a victim's identity, it would do so pursuant to a state or federal freedoin of information statute. These statutes, however, are subject to restrictions on public access. In Florida Star v. B.J.F., ${ }^{82}$ for example, the Supreme Court indicated in dictum that a state government would be entitled to protect a rape victim's identity at the investigative stage of a criminal matter if it chose to do so:

[T] he government retains ample means of safeguarding significant $\mathrm{m}$ terests upon which publication may impinge, imcluding protecting a rape victim's anonymity. ... The government may classify certain inforination, establisli and enforce procedures ensuring its redacted release, and extend a damages reinedy agamst the government or its officials where the government's mishandling of sensitive information leads to its dissemination. Where information is entrusted to the government, a less drastic means than punishing truthful publication alinost always exists for guarding against the dissemination of private facts. ${ }^{33}$

The implication of this dictum ${ }^{84}$ is that the government can keep a tight hold on information that it does not want published by restricting public access to records. Once the information is released to the public, however, the government has no constitutionally valid ineans of suppressing its dissemination. State and federal freedoin of information acts corroborate this dictum.

The federal Freedom of Information Act (FOIA), for instance, exempts from public disclosure "records or information compiled for law

81. Grand juries, which function both as investigative and as screening agents, traditionally have conducted secret proceedings. Secrecy allows the grand jury to have several powerful investigative advantages, such as keeping the target of its investigation in the dark, or hiding the investigation from public attention. See Press Enterprise II, 478 U.S. 1, 10 (1986) ("[G]rand jury proceedings have traditionally been closed to the pubhic."); Uinted States v. Sells Eng'g, Inc., 463 U.S. 418, 424 (1983) (" " $[\mathrm{P}]$ roper functioning of the grand jury systein depends on the secrecy of the proceedings.' ") (quoting United States v. Proctor \& Gamble Co., 356 U.S. 677, 681 (1958)). But see Washington Post Co. v. Robinson, 935 F.2d 282, 291 (D.C. Cir. 1991) (holding that the government cannot seal plea agreement for the purpose of proteeting secrecy of grand jury deliberations when there is no reference in the plea agreement to information revealed to the grand jury).

82. 491 U.S. 524 (1989). In Florida Star, the Supreme Court found a violation of the First Amendment when a state court imposed civil damages on a newspaper that published truthfully the legally obtained identity of a rape victim. See id. at 526.

83. Id. at 534 .

84. The statement is dictum because the case did not address the lawfulness of the Florida statute that prohibits government disclosure of a rape victim's identity. See id. at 541. 
enforcement purposes"85 to the extent that disclosure "could reasonably be expected to constitute an unwarranted invasion of personal privacy," 86 or "could reasonably be expected to disclose the identity of a confidential source."87 Either of these FOIA provisions might be used to exempt a victim's name from investigative documents. ${ }^{88}$ Similarly, the majority of state freedom of information acts contain specific exeinptions for records compiled in the course of a criminal investigation. ${ }^{89}$ Many of

85. 5 U.S.C. § $552(b)(7)(1988)$.

86. Id. $\S 552(\mathrm{~b})(7)(C)$.

87. Id. § 552(b)(7)(D).

88. Exemption $7(C)$, the law enforcement exemption, was recently construed to exempt categorically a defendant's rap sheet from public disclosure in United States Dep't of Justice v. Reporters Comm. for Freedom of Press, 489 U.S. 749, 780 (1989). See infra text accompanying notes 142-46 (discussing whether Exemption 7(C) would justify the government in redacting victims' names from FOrA requests).

Although FOIA does not specifically mention victims, a victim who desires to remain confidential might be construed as a "confidential source" for the purposes of Exemption 7(D). In Dow Jones \& Co. v. Department of Justice, 917 F.2d 571 (D.C. Cir. 1990), the D.C. Circuit construed Exemption 7(D) to protect the identity of any informant who provided information to the FBI under a promise of confidentiality. See id. at 575-76. In other words, a source will be deemed confidential under FOIA if the FBI shows that the information was solicited during the course of law enforcement investigations and the requester does not produce evidence to the contrary. See id. at 576. Thus the role of the informant in the criminal matter and the nature of the information he provided is irrelevant, as long as he provided information with the understanding that his identity would remain confidential. Using this reasoning, the government could protect any information the FBI obtained from a victim, including the victim's identity. Accord Irons v. FBI, 880 F.2d 1446, 1448 (1st Cir. 1989) (en banc) (holding that confidential information is "information provided in confidence" regardless of whether the information or the source is secret).

89. Thirty-seven states and the District of Columbia have specific exemptions in their freedom of information acts. These statutes are all slightly different in scope. Twenty-one states have a blanket exemption for law enforcement or criminal investigatory records. ARK. CODE ANN. § 2519-105(7) (Michie 1987); CaL. Gov'T Code § 6254(f) (West Supp. 1991); Colo. REv. Stat. ANN. $\$ 24-72.305(5)$ (West 1988); ConN. GEN. STAT. ANN. \$1-19(b)(3) (West 1988); Fla. STAT. ANN. $\$ 119.07(3)$ (h) (West Supp. 1991); IND. CODE ANN. \$ 5-14-3-4(b)(1) (Burns Cum. Supp. 1991); Iowa CoDE ANN. § 22.7(5) (West 1989); KAN. StAT. ANN. § 45-221(10) (Cum. Supp. 1990); LA. Rev. Stat. Ann. § 44:3(A)(4)(a) (West Cum. Pocket Part 1991); MAss. Gen. L. ch. 4, § 7, cl. 26(f) (Law Co-op. 1988); NeB. ReV. StAT. § 84-712.05(5) (1987); N.D. CENT. CoDE § 44-04-18.7 (Cum. Supp. 1991); OKLA. Stat. ANN. tit. 51, § 24A.8(B) (West 1988); OR. Rev. StaT. § 192.501(3) (Supp. 1990); Pa. Cons. Stat. ANN. tit. 65, § 66.1(2) (Purdon 1959); Tenn. Code ANN. § 10-7504(a)(2) (Supp. 1991); TeX. REv. Crv. STAT. ANN. art. 6252-17a §3(a)(8) (West Supp. 1990); UTAH CODE ANN. § 63-2-89 (1989 \& Cum. Supp. 1991) (repeal effective April 1, 1992); VT. STAT. ANN. tit. 1, § 317(b)(5) (1985); W. VA. CODE § 29B-1-4(4) (1986); Wyo. STAT. § 16-4-203(b)(i) (Supp. 1991). Four states generally exempt criminal investigative information, including the identity of any confidential informants. GA. CODE ANN. §50-18-72(a)(3)-(4) (Michie 1990); Ky. REv. STAT. ANN. § 61.878(1)(f) (Baldwin 1989); OHIO REv. CODE ANN. § 149.43(A)(2) (Baldwin 1990); S.C. CODE ANN. \& 30-4-40(a)(3) (Law. Co-op. 1976). Three states exempt records of active or ongoing investigatious. MinN. STAT. ANN. §13.82(5) (West 1988); N.J. STAT. ANN. $§ 47: 1 A-3$ (West 1989); N.Y. PUB. OfF. LAW $\S 87.2$ (e) (McKinney 1988). Nine states and the District of Columbia exempt records from disclosure if disclosure would result in an unwarranted invasion of personal privacy. ALASKA STAT. § 09.25.120(6)(C) (1990); DEL. CODE ANN. tit. 29, § 10002(d)(4) (1975); D.C. CODE ANN. § 1-1524(a)(3)(C) (1981); HAW. REV. STAT. § 92F-22(1) (1988); IDAHO 
the states without specific exemptions either classify law enforcement records as confidential in other sections of their code, ${ }^{90}$ or have case law or attoruey general opinions that construe such records as exempt from disclosure. ${ }^{91}$

The scope of these state records exemptions does not always extend to the basic facts of a crime that typically are included in complaints and incident reports. Many states distinguish between imformation that appears in complaints and incident reports and information that appears in investigative records, the former being a matter of public record and the latter a confidential matter. ${ }^{92}$ Thus, the states that are interested in protecting a victini's identity must redact the victini's naine from the complaint and incident report, even if they routmely release the factual

CODE $\S \S 9-335,9-340(22)$ (1990 \& Supp. 1991); ILL. ANN. STAT. ch. 116, para. 207(c)(vi) (SmithHurd Cum. Pocket Part 1991); MD. STate Gov'T Code ANN. § 10-618(f)(2)(iii) (1984); Mich. CoMp. LAws ANN. $\$ 15.243(1)$ (b)(iii) (West 1981); R.I. GeN. LAws § 38-2-2(d)(4) (Cum. Supp. 1990); WASH. REv. CODE ANN. § 42.17.310(1)(d)-(e) (West 1991).

90. See, e.g., ME. REv. STAT. ANN. tit. 25, 1631 (West 1964) (keeping all criminal records of police departments confidential, except information on pending cases that would not jeopardize the investigation); MISs. CODE ANN. § 45-29-1 (Supp. 1990) (exempting certain iuvestigative and criminal justice records from category of "public access records"); NEV. REV. STAT. ANN. § 179A.070 (Michie Supp. 1989) (excluding investigative and intelligence information from the crininal history information that is part of the public record); S.D. CoDIFIED LAws ANN. § 23-5-11 (1988) (denying application of state freedom of information act to "confidential criminal justice information").

91. See, e.g., Stone v. Consolidated Publishing Co., 404 So. 2d 678, 681 (Ala. 1981) (exempting from state freedom of information act all information from a confidential source, relating to pending criminal investigations, and information "the disclosure of which would be detrimental to the best interests of the public"); Little v. Gilkinson, 636 P.2d 663, 665 (Ariz. 1981) (allowing police to keep investigative records confidential ouly if disclosure would have a harmful effect on the conduct of official duties); Hyde v. City of Columbia, 637 S.W.2d 251, 263 (Mo. Ct. App. 1982) (holding that the name and address of a crime victim who can identify an assailant not yet in custody is not a public record under the Sunshine Law), cert. denied, 459 U.S. 1226 (1983); Engrav v. Cragun, 769 P.2d 1224, 1229 (Mont. 1989) (disallowing right to see records of sheriff's department, and holding that individual privacy interest in criminal investigative files derives from state freedoun of information laws); 83 Nev. Op. Att'y Gen. 14 (1983) ('[C]riminal investigation reports . . . are confidential as internal intelligence and investigative records collected in the course of the enforcement of crininal laws and are not public records subject to [inspection under NEV. REV. STAT. $\$ 239.010$ (Michie Supp. 1989)]."); 44 N.C. Op. Att'y Gen. 340 (1975) (“Sheriff's department investigative reports and memoranda concerning investigation of crimes are not public records within the sense of [N.C. STAT. § 132 (1990)] and are not thereby subject to public imspection."); 1979 N.D. Op. Att'y Gen. 201 (balancing policy of public right of access agaimst policy of efficient operation of state government to find that police blotter information was a matter for disclosure, but that investigative inaterials were not).

92. See, e.g., IowA CODE ANN. \& 22.7(5) (West 1989) (providing general exemption for police investigative reports, except for immediate facts and circumstances surrounding a crime); LA. REV. STaT. AnN. \& 44:3(A)(4)(a) (West Cum. Pocket Part 1991) (providing general exemption for law enforcement records, except for the initial report of a complaint); N.D. CENT. CODE § 44-04-18.7 (Cum. Supp. 1991) (giving exemption for active criminal investigative information, not including facts concerning the initial offense report); OR. REV. STAT. $\$ 192.501(3)$ (Supp. 1990) (allowing exemption for law enforcenent records including the identity of the victin but excluding incident 
information about a crime. Some states will protect the identity of a victim of any crime if the victim is a minor ${ }^{93}$ or if disclosure would somehow endanger the victim's physical safety. ${ }^{94}$ Other states restrict access to a victim's identity for a broader range of reasons, including to protect the victim's privacy. In Alaska, for example, the government will refuse to release any law enforceinent records if such a release would result in "an unwarranted invasion of the personal privacy of a . . victim." 95 At least six states distimguish between victims of sexual crimes and the victims of all other crime, protecting the confidentiality ouly of the former. ${ }^{96}$

reports). See Access Guide, supra note 60, at 3-11 (providing state-by-state analysis of records disclosed by the police). According to the Access Guide, 30 states and the District of Columbia release complaints and incident reports. These states are California, Delaware, Florida, Georgia, Idaho, Indiana, Iowa, Kentucky, Maryland, Michigan, Minnesota, Montana, Nebraska, Nevada, New Jersey, New York, North Dakota, Ohio, Oregon, Rhode Island, South Carolina, South Dakota, Tennessee, Texas, Utah, Vermont, Virginia, Washington, West Virginia, and Wyoming. Id. By contrast, arrest rccords and police blotter information are never exeinpted from public disclosure for the purpose of protecting against secret arrests. See infra note 125.

93. Nineteen states protect the confidentiality of minor victims of crimes. NATIONAL ORGANIzATION FOR Victims ASSISTANCE, VICTIM RIGHTS AND SERVICES: A LEGISLATTVE DIRECTORY 1988/1989, at 18, 33-47 [hereinafter Victim Rights]. See, eg., N.Y. Civ. Righis LAw § 50-b(1) (McKinney Supp. 1991) ("The identity of any victim of a sex offense ... who was nnder the age of cighteen at the time of the alleged commission of such offense, shall be confidential. No report, paper, picture, photograph, court file or other documents, in the custody or possession of any public officer or employee, which identifies such a victnn shall be made available for public inspection.")

94. See, e.g., CAL. Gov'T CODE $\$ 6254(f)$ (West 1991) (identifying information about a victim may not be released if it would endanger a victim's safety); OHIO REV. CODE ANN. $\S 149.43(\mathrm{~A})(2)(\mathrm{d})$ (Baldwin 1990) (exempting from freedom of information requests "[i]nformation that would endanger the life or physical safety of . . a crime victim"); WASH. REV. CODE ANN. \$ 42.17.310(1)(e) (West 1991) (exempting disclosure of complainant's identity if disclosure would endanger "life, physical safety, or property"); see also Hyde v. City of Columbia, 637 S.W.2d 251, 263 (Mo. Ct. App. 1982), cert denied, 459 U.S. 1226 (1983) ("[T] crime who can identify an assailant not yet in custody is not a public record nnder the Sunshine Law.").

95. Alaska Stat. \$ 9.25.120(6)(C) (Cum. Supp. 1991); see also Mich. CoMp. Laws ANN. $\S 780.769$ (West Supp. 1991) ("A victim's address and telephone number maintained by a sheriff ... pursuant to a request for notice under [the state freedom of information act] shall be exempt froin disclosure."); VA. CODE ANN. \$ 2.1-341 (Michie Supp. 1991) ("[T]he identity of any victim, wituess, undercover officer, or imvestigative techriques or procedures need not but may be disclosed" in a request for criminal incident information.).

96. See, eg., CAL. Gov't Code § 6254(f)(2) (West Supp. 1991) (disallowing release of identities of victims of sex crimes if victim so requests); CoNN. GEN. STAT. ANN. § 1-19(b)(3)(E) (West 1988) (prohibiting release of investigative records if release would result in disclosure of "the name and address of the victim of a sexual assault"); FLA. STAT. ANN. $\$ 119.07(3)(h)$ (West Supp. 1991) (exempting from disclosure "criminal intelligence information or investigative information including the photograph, name, address, or other fact or information which reveals the identity of the victim" of any sexual offense); IND. CODE ANN. \$ 5-14-3-5(c)(3)(B) (Burns 1987) ("If an agency maintains a daily $\log$ or record that lists ... complamts, the following information shall be made available for inspection and copying: . . . [t] he nane and age of any victim, unless the victim is a victim of a [sex crime]."); OR. REV. STAT. \$ 192.501(3) (Supp. 1990) (exempting investigatory information except 
Texas law provides an example of a restrictive public records scheme. The Texas freedom of information statute contaims a specific exemption for law enforcement records. ${ }^{97}$ In 1975, however, a state court announced that the press is "constitutionally" entitled to the front page of an offense report, which includes the victinn's identity and a description of the complainant. ${ }^{98}$ The Texas Attorney General has since written opinions stating that the identity of a victin of "aggravated sexual abuse" is "deemed confidential by law," 99 but that the identities of burglary victinis are not private. ${ }^{100}$ Texas also has a rule of criminal procedure that permits the victim of a sex crime to be designated by a pseudonyin in all pubhic files, imcluding court records. ${ }^{101}$

In contrast to Texas, at least two states have adopted pohicies that affirmatively make the victim's naine a part of the public record. In Kentucky, for example, the attorney general has written that "the public interest in police busmess outweighs any privacy interest of victuns, offenders, or pohice persounel. ... [A] police department cannot adopt a policy of withholding the naines of victims of crime, imcluding the crime of rape."102 In Oregon, the public records law provides that arrest records and incident reports are not confidential, including "[t]lhe identity of and biographical information concerning both complaining party and victim."103

States need not rely on public records statutes to restrict public access. Civil and criminal laws can be used explicitly to protect the confidentiality of crime victims at the investigative stage of a criminal inatter

for crime reports, including the identity of the complaining party and the victim); WYo. STAT. § 6-2310 (a) (1977) (restricting pre-indictment release of identity of victim of sexual assault).

Minnesota protects the privacy of all sex crime victims unconditionally, but only protects the identity of other crime victims if "the victin or witness specifically requests not to be identified publicly, and the agency reasonably determines that revealing the identity of the victim or witness would threaten the personal safety or property of the individual ...." MiNN. STAT. ANN. § 13.82 subd. 10(b), (d) (West Supp. 1991). Soine states also provide statutes that protect the confidentiality of communications between victims of sex crimes and their counselors. See Victim RighTs, supra note 93, at 22-23, 33-47.

97. See Tex. Rev. Civ. Stat. ANN. art. 6252-17a, § 3(a)(8) (West Supp. 1990).

98. See Houston Chromicle Publishing Co. v. City of Houston, 531 S.W.2d 177, 187 (Tex. Civ. App. 1975).

99. Tex. Op. Att'y Gen. Open Rec. Dec. 339 (1982).

100. See Tex. Op. Att'y Gen. Open Rec. Dec. 409, at 3 (1984) (opining that name of burglary victim is not "highly intimate or einbarrassing" and thus is not protected from disclosure).

101. TeX. CODE Crim. Proc. ANN. art. 57.02(b) (West Supp. 1991) ("A victim lof a sexual offense] may clroose a pseudonym to be used instead of the victim's name to designate the victim in all public files and records concerning the offense, including police summary reports, press releases, and records of judicial proceedings.").

102. 80 Op. Att'y Gen. Ky. 54 (1980).

103. OR. REv. STAT. § 192.501(3)(d) (Supp. 1990). But see id. § 135.970 (preventing disclosure of victim's biographical information to defendant). 
and beyond. ${ }^{104}$ In Massachusetts, for example, a statute provides that the records of any court or police department that contain the identity of a victim of a sex crime "shall not be deemed to be a public record"; 105 disclosure of such information is punishable by a fine. ${ }^{106}$ This statute enables the Massachusetts state government to redact a victim's name from every public record that it releases to the public. Paul Marcus and Tara L. McMahon have recently suggested a model statute that imposes civil sanctions on "any entity or individual" who intentionally discloses the identity of a rape victim "prior to open judicial proceedings" in a criminal matter. ${ }^{107}$ This statute is intended to perimit states to protect the confidentiality of crime victims without violating the public's constitutional riglit of access to information about the criminal justice system. Marcus and McMahon base their statute on the majority opimion in Florida Star v. B.J.F., ${ }^{108}$ which qualified its holding by stating that "[w]e accordingly do not rule out the possibility that, in a proper case, imposing civil sanctions for publication of the name of a rape victim might be so overwhelmingly necessary" that to do so would not violate the First Amendment. ${ }^{109}$

The first Globe factor reveals a mixed historical tradition of access to a victim's identity at the investigative stage of a criminal matter. When the First Amendment was ratified, the community was actively involved in the investigative process and would have been fully informed about a victim's identity; the historical tradition thus favors access. In contrast, the state laws canvassed in this section show that the current practice of public access conflicts with the historical tradition. State and federal governments currently enjoy broad discretion over the information they release to the public at the investigative stage, including the basic factual information released in complaints and imcident reports. Most states release victims' names, but a growing number restrict access to a victim's identity for the purpose of protecting that victim's privacy. ${ }^{110}$

104. See infra note 176.

105. MAss. AnN. LAws ch. 265, \& 24C (Law. Co-Op. Supp. 1991) ("That portion of the records of a court or any police department... whicls contains the name of the victim in an arrest, investigation or coinplaint for rape or assault with intent to rape ... shall be withheld from public inspection ... [and] slaall not be deemed to be a public record ....").

106. Id.

107. See Paul Marcus \& Tara L. McMahon, Limiting Disclosure of Rape Victims Identities, $64 \mathrm{~S}$. CAL. L. REv. 1020, 1052 (1991). The autlors did not specify which records were implicated "prior to open judicial proceedings" in a criminal matter, except to say that their statute would not apply to the "trial." See id. at 1021 n.3, 1053.

108. 491 U.S. 524 (1989).

109. Id. at 537.

110. See supra notes $3-4,6,7,59-61,92-96,104-06$ and accompanying text. 
Although the traditions of access are mixed, two aspects of Globe analysis weigh in favor of a public right of access to a victim's identity. First, many states release basic factual information about a crime even if they restrict access to other investigative material. Second, Supreme Court cases have shown that the historical inquiry is inore significant than the inquiry into current practices. ${ }^{111}$ In conclusion, the historical analysis favors a public right of access to a victim's identity at the investigative stage of a criminal matter.

2. The Second Globe Factor: Functional Value of Public Access. In Richmond Newspapers, Globe, and the Press-Enterprise cases, the Supreine Court histed various functional values associated with public access to the criminal justice system at the pre-trial and trial stages: Public access enhances the quality and safeguards the integrity of factfinding; it enhances the appearance of fairness and therefore proinotes public respect for the system and public confidence in its fairness; it ensures that uniform procedures are used in all cases; it can function as a substitute for the jury in bench trials; it provides a community outlet for rage; and it functions as a clieck on state abuses of power. ${ }^{112}$ Soine of these functional values associated witl public access at the trial would not be enlanced by public access to investigative information. For example, there is no fact finding, uniform procedure, or jury participation in a criminal investigation. Nevertleless, public access at the investigative stage of a criminal matter serves several vitally important functions: It warns the public of potential safety liazards; ${ }^{113}$ it functions as a coininunity outlet

111. See supra text accompanying notes 66-68.

112. See Press-Enterprise II, 478 U.S. 1, 12-13 (1986); Press-Enterprise I, 464 U.S. 501, 508-09 (1984); Globe Newspaper Co. v. Superior Court, 457 U.S. 596, 606 (1982); Richmond Newspapers, Inc. v. Virginia, 448 U.S. 555, 569 (1980); Gannett Co. v. DePasquale, 443 U.S. 368, 383 (1979). In Press-Enterprise II, the Supreme Court seemed to emphasize the functional role of the preliminary hearing in California over the tradition of access to such proceedings. 2 LAFAVE \& ISRAEL, supra note 78, $\S 22.1$, at 270-71 (Supp. 1991). Although the tradition of access to preliminary hearings in this country is mixed, the Court found that public presence at preliminary hearings served important functional purposes: The preliminary hearing $\mathrm{i}$ California is often the only proceeding in a criminal matter; the public compensated for the absence of a jury in those hearings; and denying access would thwart the " "community therapeutic value" " of openness im the criminal justice system. Press-Enterprise II, 478 U.S. at 12-13. These values satisfied the Court's requirement that public access play "a significant positive role in the functioning of the particular process in question." Id. at 8.

113. According to Karen Dillon, a police reporter for tlie Sarasota Herald-Tribune, reporting the victim's name and claracteristics enhances her ability to warn the public about safety hazards. Dillon claims that a member of the public is more likely to pay heed to a warning to be careful, or to be on the lookout for ccrtain suspects, if he can syinpathize or identify with the victim. If the reader happens to live in the victim's neighborhood or know the victim, then tle impact of the story will be even greater. Telephone Interview with Karen Dillon, Police Reporter for the Sarasota HeraldTribune (Sept. 3, 1991). Furtherniore, public infornation campaigns about crime have a significant impact on reducing the imcidence of crime. Garrett J. O'Keefe \& Kathaleen Reid, Media Public 
for rage ${ }^{114}$ and allows for an outpouring of sympathy for the victim; ${ }^{115}$ it turns up more evidence about the case; ${ }^{116}$ and it functions as a check on potential abuses of state investigative power. ${ }^{117}$

The inedia, as the commumity's representative, perform this last function by independently investigating criminal incidents. Besides just reporting the facts of a criminal incident, crime reporters momitor pohice mvestigative action. This requires interviewing the victim, the suspect, the pohice, and any witnesses, and tracking the progress of the incident until it goes to trial. ${ }^{118}$ Such reporting has a significant impact on the pohce. Frequently, inedia investigations uncover pohce bungling, expose arrests inade without probable cause, ${ }^{119}$ influence long- and short-term pohicy decisions inade by pohice and prosecutors, ${ }^{120}$ or bring new evidence and witnesses to light. ${ }^{121}$

The media thus function as overseers of the criminal investigative process; public access to information at the investigative stage is crucial if

Information Campaigns and Criminal Justice Policy-Beyond "McGruff," in ThE MEDIA AND Criminal Justice Policy: Recent Research and Social EFFects 220-21 (Ray Surette ed., 1990) [hereinafter The Media ANd Criminal Justice Policy].

114. If the public knows that a crime is being investigated then it will not turn to vigilante ineans of vindication. See Richmond Newspapers, 448 U.S. at 571 ("Without an awareness that society's responses to criminal conduct are nnderway, natural human reactions of outrage and protest are frustrated and may manifest themselves in soine form of vengeful 'self-help' . . . .").

115. Public interest in a victim's identity is not always notivated by morbid and prurient curiosity. Karen Dillon states that one inportant reason for reporting a crime victim's name is that it fosters an outpouring of community sympathy for the victim. Telephone Interview with Karen Dillon, supra note 113. See infra notes 160-64 and accompanying discussion of reasons to publish a victim's name.

116. Telephone Interview with Karen Dillon, supra note 113.

117. Telephone Interview with Fred Barbash, National Editor of The Washington Post (Dec. 17, 1991).

118. Teleplione Interview with Karen Dillon, supra note 113. Once a ease goes to trial, a court reporter takes over. Id. See generally DeNNISTON, supra note 79, at 83-93.

119. Telephone Interview with Karen Dillon, supra note 113 (rccounting stories of botched investigations and abusive arrests inade for retaliatory purposes that she has brought to public attention).

120. See Jack C. Doppelt \& Peter M. Manikas, Mass Media and Criminal Justice Decision Making, in The Media AND CRIMINAL Justice Policy, supra note 113, at 129; Ray Surette, The Media and Criminal Justice Public Policy-Future Prospects, in The Media AND Criminal JusTICE POLICY, supra note 113, at 304. According to Fred Barbash, The Washington Post's relentless reporting of homicide in the District of Columbia has pnt public officials under tremendous political pressure. Teleplione Interview with Fred Barbash, supra note 117.

121. Telephone Interview with Karen Dillon, supra note 113. Reporting brings new evidence to light in one of two ways: Either the reporter finds a previously unknown witness, or the publicity generated by the reporter's stories motivates witnesses to offer their knowledge to the police or the suspect. Id. Recognizing that the public can be crucial in investigating criminal matters, soine states have enacted "Crime Stoppers" programs in which the media and the police cooperate to solve crines. See Paul J. Lavrakas et al., Media Cooperation with Police: The Case of Crime Stoppers, in The Media ANd CRiminal Justice Policy, supra note 113, at 225. 
the media are to perform this function well. A victim's identity is significant to the media for several reasons. The media need to know a victim's name for the purpose of writing a complete story. As a matter of principle, the media tries to furnish the public with complete information. ${ }^{122}$ Knowing the victim's identity allows a reporter to interview the victim, thereby allowing the reporter to publish or broadcast accounts that represent all sides of a story. This function promotes fairness in the public perception of the mcident. 123

Furthermore, knowing details about a crime such as the victim's name facilitates the media's investigation of potential abuses of power. In certain situations, the victim's identity might tip off the public to improper prosecutorial motives. For example, if the press learns that the police are imvestigating the brutal beating of the pohice chief's son, then they are likely to scrutinize the progress of the imvestigation to ensure that the police are conducting reasonable investigations and are arresting suspects based on probable cause, not just rounding up suspects based on retaliatory motives. A victim might also have improper reasons to conceal his identity. A victim with a history of making false accusations would want to prevent reporters from uncovering evidence relating to the victim's credibility and could do so if the victim could protect his identity. Reporters can not know im advance whether a detail such as a victim's identity will uncover some kind of abuse; if the reporter never has access, she will never know. ${ }^{124}$ In the unusual case im which a victim's identity is connected with an improper prosecutorial motive, early public access to the identity of the victim is crucial to prevent a miscarriage of justice. ${ }^{125}$

122. Telephone Interview with Fred Barbash, supra note 117.

123. Telephone Interview with Karen Dillon, supra note 113. Karen Dillon also noted that a viction who keeps his name out of the press can hurt his credibility, both in the eyes of the public and in the eyes of the judge (Dillon believes that judges read newspapers). Id. Michael Gartner, president of NBC Nightly News, justified his decision to broadcast the name of the alleged victim of the William Kennedy Smith rape in this way: "[I] [Snnith] is never charged, he'll go through life scarred, and I think that a one-sided story was developing and that probably was taken into consideration in our newsroom .... [Y] ou try to give the viewer, the reader, as full a story as you're capable ... of giving, and to us that mcant names on both sides of this issue." Nightline: NY Times, NBC Name Palm Beach Rape Victim (ABC television broadcast, Apr. 17, 1991) [hereinafter Nightline].

124. Telephone Interview with Fred Barbash, supra note 117; DENNISTON, supra note 79, at 83 ("The least detail in any of the stages of the criminal justice system-from the point of arrest to the point of conviction-can make the difference in the ultimate outcome of a case. It is a legal axiom that when a person's biberty is at stake, the smallest details of his case can and often do count significantly.").

125. A suspect who is under order not to reveal the victim's name could not alert the media to a potential abuse of power and would have difficulty gathering evidence to support his contentions that he was being held for improper reasons. Furthermore, it would be impossible to fashion a rule that would protect a victnn's identity in cases in which the victim was inerely asserting a privacy interest 
The arguments against public access tend to focus on the liarmful effects that publishing a victim's identity might liave at the investigative stage. Certain victims, especially those who fear embarrassment from publicity, miglit be deterred from reporting a crime. ${ }^{126}$ This argument ignores the distimction between publishing and access. The press need not publish the victims' naines to conduct their investigations, ${ }^{127}$ but they do need access to those names. One newspaper editor commented that newspapers exist for the purpose of gathering information: Reporters want to know everything, but they do not necessarily write or publish stories about everything they know. ${ }^{128}$ Marcus and McMahon have also argued that there is no functional value associated with access to a rape victim's identity: "A rape victim's naine is clearly not a piece of information relevant to the public's self-governing choices," nor "tlie type of information the public needs in order to evaluate the services provided by government." 129 This assertion underestimates the importance of basic factual information about a crime to the media's ability to perform their overseeing function. Because the media typically do not have access to investigative records, they must rely on the information gleaned froin complaints, mcident reports, and police blotters. Without the victim's name, a reporter would have to atteinpt to locate the victim imdependently, by relying on unofficial and confidential sources, by talking to suspects and witnesses, or by snooping around the victim's neigliborhood

and cases in which the state or the victim was protecting the victim's identity to conceal improper motives.

It is similarly impossible to protect an arrestee's privacy by protecting arrest reports and police blotters from public access. It would be too difficult to distinguish between "secret arrests" and arrests in which the arrestee merely wanted to protect his privacy. See, eg., Morrow v. District of Columbia, 417 F.2d 728, 741-42 (D.C. Cir. 1969) (stating that arrest record is inade public to guard against secret arrests, "a concept odious to a democratic society"); Dayton Newspapers v. City of Dayton, 341 N.E.2d 576, 579 (Ohio 1976) (holding that jailer's log must be kept public to protect key constitutional rights of defendants); Newspapers, Inc. v. Breier, 279 N.W.2d 179, 189 (Wis. 1979) (finding that statutory and common law presumption of openness of arrest records outweighs the interest in protecting the reputations of persons arrested). Suspects' names are generally kept secret until there has been an arrest, with the rare exception for "fannous" suspects. See Diane Klein, Some Lessons About Rape Have Yet to Be Leamed, L.A. TIMEs, Apr. 25, 1991, at E1 ("Once word of the Kennedys' involvement was out, however, there wasn't a prayer of keeping it under wraps.").

126. 2 LAFAVE \& ISRAEL, supra note $78, \S 22.1$, at 751 . The reporting of crimes at the investigative stage also has the potentially detrimental effect of thwarting investigations (e.g., by causing the suspect to flee) and exposing certain persons - such as undercover agents, witnesses, or victimsto personal danger. Id. See infra notes 156-58 and accompanying discussion.

127. In fact, most newspapers do not publish the names of rape victims. See infra notes 168-169 and accompanying text.

128. Telephone Interview with Fred Barbash, supra note 117.

129. Marcus \& McMahon, supra note 107 , at 1045. 
if the incident took place in his residence. ${ }^{130}$ Even if a reporter were able to learn a victim's name through unofficial sources, any strictures on access to such information are bound to have a "chilling effect" on a reporter's willingness to track down the information and interview the victim. ${ }^{131}$

The second part of the Globe test therefore reveals that public access to a victim's identity at the investigative stage of a criminal matter is essential to the public's systemic overseeing function. Access facilitates media investigations into criminal incidents and is crucial if the media are to act as a check on state abuse of power. Permitting a state to obstruct the inedia from engaging in its lawful - and vitally importantactivity as an independent check on the criminal justice systein would raise serious concerus about the integrity of the state-run system. The result would be a concentration of power in government without adequate public opportunity to supervise-an inapt arrangement in a selfgoverning society, and one that the First Amendment right of access helps prevent. Access to factual details about a crine can be vital to preventing a miscarriage of justice. Public access to victimis' identities therefore satisfies the Supreine Court's requirement that public access play "a significant positive role in the functioning of the particular process in question."132

\section{B. The Government Does Not Have a Compelling Interest in Protecting a Victim's Identity for Privacy Reasons}

Based on the historical and functional analyses just conducted, this Note concludes that the public has a right of access to a victim's identity, and that this information is presumptively open to the public unless the government asserts a coinpelling reason for denymg access. This Note also adopts the position that the governinent should not exempt a victim's identity froin disclosure under freedoin of information requests, nor exclude the victim's identity froin complaints or incident reports, when the sole justification is to protect an adult victimi's privacy. ${ }^{133}$ This Section discusses soine of the legal and policy issues that counsel against protectimg an alleged victim's privacy interests.

130. Telephone Interview with Karen Dillon, supra note 113.

131. Id.

132. Press-Enterprise II, 478 U.S. 1, 8 (1986).

133. The privacy interest belongs to the victim even though the governinent must present a coinpelling reason to protect that interest. This Note does not extend its argument to situations in which the government protects a victim's identity for the purposes of guarding against further bodily injury or threats of injury, or when the government protects a ininor victim's identity. 
1. Nature and Scope of a Victim's Privacy Interest. To determine whether a victim's privacy interest at the investigative stage of a criminal matter could be deemed a compelling reason to restrict access, it is important to consider the precise nature and scope of the victim's privacy imterest in his identity after he reports an incident to the pohice. A victim's privacy interest at the investigative stage is too ambiguous to be compelling. It is not clear that the right has a clear boundaries or a solid grounding in the law, that victims desire privacy at that stage, or that privacy is beneficial to victims or to society.

First of all, the precise source of the alleged victim's privacy right in his identity is inurky, although there are three possible sources of derivation: the common law, constitutional doctrine, or the Supreme Court's interpretation of FOIA. Under common law doctrine, all persons have a privacy interest in the private facts of their life. ${ }^{134}$ Rape victims who have sued over the publication of their names have a cause of action for the publication of a private fact. ${ }^{135}$ This tort rehes upon the view that persons should not be subject to public disclosure of facts that would be "highly offensive and objectionable to a reasonable person of ordinary sensibilities." 136 In Texas, the Attorney General based a victim's privacy interest in certain public records on common law notions of privacy, stating that privacy adheres in the "highly intunate or embarrassing" details of a person's life. ${ }^{137}$ Therefore, aceording to common law, the disclosure of the victim's name is not, in itself, a violation of privacy; rather, the disclosure of a victim's name in conjunction with details of a crime that are highly offensive, intimate, or embarrassing violates the victim's privacy interest. This tort-related reasoning could be used by a government to justify its protection of the identity of any victim of a gruesome personal assault, although it does not provide a compelling argument for nondisclosure of the names of most victims of purse snatching, burglary, or robbery. ${ }^{138}$

A victim's privacy interest might also stem from the loosely defined penumbra of the Bill of Rights that protects individuals' autonoiny im making decisions of a highly personal nature. The Supreme Court has

134. According to Dean Prosser, a person has no exclusive right to the use of his name and no remedy for another's use of his name unless his identity has been appropriated for some advantage of another. W. PAGe KeEton ET AL., Prosser \& KeEtoN ON THE LAW OF TORTS § 117, at 852 (5th ed. 1984).

135. See infra notes $185-87$ and accompanying text.

136. KEETON, supra note 134 , § 117 , at $856-57$.

137. Tex. Op. Att'y Gen. Open Rec. Dec. 409 (1984); see also Tex. Op. Att'y Gen. Open Rec. Dec. 339 (1982).

138. See, e.g., Tex. Op. Att'y Gen. Open Rec. Dec. 409 (1984) (concluding that name of burglary victim is not "highly intimate or embarrassing" and thus is not protected from disclosure). 
protected a married couple's right to make choices about contraception, ${ }^{139}$ and a woman's right to make choices about procreation. ${ }^{140}$ An individual victim's choice to disclose his identity to the public could be considered a highly personal one. This would especially be true if such a disclosure would reveal facts about the victim's body - that it was penetrated, for example-or involve descriptions of areas of the body about which the victim has a high expectation of privacy. ${ }^{141}$ This argument for a constitutional source of a victim's privacy right is only compelling if a victim has the right to make a decision to disclose his identity. Based on the Globe test, however, the public has a right of access to the victim's identity. Thus, the choice to disclose does not belong to the victim.

A victim's privacy right in his identity might be comparable to a defendant's privacy right im his rap sheet. If so, then crime victims retain a substantial privacy interest in their identities even though their identities have become part of a government record. This reasoning is based on Department of Justice v. Reporters Committee for Freedom of the Press, ${ }^{142}$ a FOIA ease in which a media advocacy group challenged the Justice Department's policy of keeping rap sheets confidential, alleging that the privacy interest in a rap sheet did not invoke the federal government's FOIA exemptions. The Supreme Court upheld the Justice Department's policy for two reasons. First, individuals have a "substantial" privacy interest in their rap sheets because privacy interests are not eradicated by the simple fact that private information becomes part of a public record.143 This position is consistent with the common law, in which privacy interests rely in part upon the degree that private information had been dissemmated. Thus, the "interests in privacy fade" but do not disappear, once information has been entered into government records. ${ }^{144}$

139. See Griswold v. Connecticut, 381 U.S. 479 (1965).

140. See Roe v. Wade, 410 U.S. 113 (1973).

141. See, e.g., United States ex rel. Latinore v. Sielaff, 561 F.2d 691, 694 (7th Cir. 1977) ("Rape constitutes an intrusion upon areas of the victim's life, both physical and psychological, to which our society attaches the deepest sense of privacy.").

142. 489 U.S. 749 (1989).

143. See id. at 770-71 ("In sum, the fact that 'an event is not wholly "private" does not mean that an individual has no interest in limiting disclosure or dissenination of the information." ") (quoting William H. Rehnquist, Is an Expanded Right of Privacy Consistent with Fair and Effective Law Enforcement?, Nelson Tinnothy Stephens Lectures, University of Kansas Law School, Pt. 1, at 13 (Sept. 26-27, 1974)).

144. Id. at 763 n.15 (quoting Cox Broadeasting Corp. v. Cohn, 420 U.S. 469, 494-95 (1975)). Samuel $\mathbf{D}$. Warren and Louis $\mathrm{D}$. Brandeis expressed a sinnilar view in their influential article, The Right to Privacy, 4 HARV. L. REv. 193 (1890): "The general object in view is to protect the privacy of a private life, and to whatever degree and in whatever conneetion a nan's life has ceased to be private, before the publication under consideration has been nuade, to that extent the protection is to be withdrawn." Id. at 215 . 
The second reason that individuals have a substantial privacy interest in their rap sheets is that releasing the rap sheet would not serve FOIA's basic purpose: 'to ensure that the Government's activities be opened to the sharp eye of public scrutiny, not that information about private citizens that happens to be in the warehouse of the Government be so disclosed." 145 This rationale potentially undermines the notion that the public must have access to all information surrounding criminal matters. Reporters Committee teaches that results in individual cases are not crucial to systemic overseeing because "rap sheets reveal only the dry, chronological, personal history of individuals who have had brushes witli the law, and tell us nothing about matters of substantive law enforceinent policy that are properly the subject of public concern."146

Reporters Committee provides an argument in favor of withholding a victimi's identity at the investigative stage of a criminal matter. If the public's overseeing function does not implicate a criminal rap sheet, then it certainly does not implicate the victim's identity on a complaint or incident report. Like rap sheets, coinplaints are inerely the dry, factual reports of one individual's brushes witl tlie criminal element. Rap sheets are not, however, comparable to complaints and incident reports. First of all, coinplaints do not report the results of individual cases. Instead, they indicate the imitiation of the criminal process. More importantly, complaints are useful for investigating a criminal incident or overseeing an investigation; by contrast, the rap sheet in Reporters Committee was sought for the purpose of writing an expose of a political candidate-an activity that did not implicate the integrity of the criminal justice systen.

The final ambiguity surrounding a victim's privacy interest im his identity concerns its definition. The victim's privacy interest is not susceptible to clear definition, boundaries, and limits. Statutes typically define the privacy interest as including identifying information sucli as the victim's naine, address, telephone number, and place of einployinent. ${ }^{147}$ None of the states that protect victims' identities limit access to any other facts of the criminal incident. ${ }^{148}$ On their face, these statutes appear to limit access only to specific information about a victim, but in reality they announce no clear limiting primciples. If the state restricts access to naine, address, and place of einployment, it could just as easily restrict access to information such as the victim's age, sex, race, hair color, and

145. Reporters Committee, 489 U.S. at 774. The Court has consistently rejected requests for information in government files about private citizens. See id. at 780 .

146. Id. at $766 \mathrm{n} .18$.

147. See, e.g., Mich. Comp. Laws ANN. § 780.769 §.19(2) (West Supp. 1991).

148. See supra notes 95-96. Marcus and McMahon also limit their model statute to protecting the victims' "names or other identifying information." Marcus \& McMahon, supra note 107, at 1052. 
eye color. It might also be able to justify omitting certain details of the incident, such as the type of weapon used and the type of injury the victim suffered, as these could be considered private information because they are details connected with a particular individual's life. In short, there is no inherent limiting principle to the scope of the victim's privacy interest in his identity; such a privacy interest could be expanded to the point where the public can be excluded from discovering even the inost rudimentary facts about a criminal incident.

In conclusion, the victim has an ascertainable but ill-defined privacy interest in protecting his identity. The interest is not precisely identified in the common law or in constitutional law. Nor is there a limiting principle on the interest, which gives it to the potential to expand to the point of seriously impeding the public's interest in access to information about the occurrence of crime in the community. However, the Supreme Court's recent interpretation of FOIA suggests that citizens retain some kind of privacy interest in information that has becoine part of a governinent record. 149

2. Dubious Benefits of Protecting a Victim's Privacy Interest. The policy debate about the public disclosure of victinns' naines has focused on the effect of publishing a rape victim's identity. This Note argues that the harmful effects of publicity do not present a coinpelling arguinent in favor of withholding a victim's identity froin the public.

First of all, not all crime victims, even rape victims, desire to remain anonymous. Some actively seek publicity to pronrote social awareness of criminal issues. 150 Because restricting access to these names intrudes upon a significant public interest, the government does not have a coinpelling interest in protecting a victim's confidentiality unless the victim expressly requests it. ${ }^{151}$ Furthernore, the current victim's rights movement has not focused on obtaining privacy rights for victims. Instead, the typical "Victim's Bill of Rights" focuses on obtaining compensation and enrergency aid for victins, inforination about the status of the case

149. See also infra text accompanying notes 178-96 (discussing victim's privacy rights at trial).

150. See, e.g., Donna Drejza, A Woman Who Was Raped Reveals Her Name, WASH. Post, Sept. 3, 1991, at Z8 (reporting rape victinn's revelation of her name, her story, and her plea for other rape victims to stop hiding their identities); Michael Isikoff, Families Touched by Tragedy Plead for Handgun Bill; Bereaved Parents Urge Congress to Impose Week-Long Waiting Period on Purchases, WASH. Post, Mar. 22, 1991, at A8 (describing testimony of families of murder victins before Congress in favor of liandgun regulation); Jane Scliorer, It Couldn't Happen to Me: One Woman's Story, DEs MOINEs REG., Feb. 25-Mar. 1, 1990 (Pulitzer prize-winning series of five articles in which Nancy Ziegenmeyer told lier story of being raped).

151. Contra In re Radio City Music Hall Prods., Inc., 503 N.Y.S.2d 722, 723 (App. Div. 1986) (permitting a police department to redact a victin's name from the records it released even though the victin clearly did not object to the release of that information). 
and the scheduling of proceedings, and increased participation in criminal proceedings. ${ }^{152}$

In the case of rape, commentators are split over which causes greater injury to a victim: public disclosure of identity, or the perpetuation of the stigma of being a victim caused by the secrecy surrounding a rape victim's identity. Marcus and McMahon, for example, argue that "routine disclosure" of rape victims' names to the inedia liarms the victim by interfering with the healing process, focusing attention on the victim instead of on the source of prejudicial views (i.e., society), and burdening the victim witl the task of educating society. ${ }^{153}$ Mental health experts have also argued that giving a rape victim control over the publication of her name helps the victim to regaim a sense of control, thereby aiding recovery. ${ }^{154}$ Soine victim advocates have compared inedia publication of a rape victim's name to the public "outing" of closet hoinosexuals because botli are events in which a private fact about an individual is forcibly disclosed. ${ }^{155}$

Many rape-victim advocates argue that victim confidentiality is essential to ensure that rape victims will not be afraid to come forward and report the crime. ${ }^{156}$ Susan Estrich recently wrote that " $[t] 0$ this day, woinen call iny office for advice and are ashamed to leave their names, afraid to be identified as rape victims even to ine [a famous rape victim

152. See VICTIM RIGHTS, supra note 93 , at 6-8, 213, 217 (explaining the typical victim's rights and reproducing two victin's bills of rights). According to the National Organization for Victim Assistance (NOVA), 45 states have passed some förm of victim's rights legislation. Id. at 7; see also Robert ReifF, The Invisible Victim: The Criminal Justice System's Forgotten ResponSIBILITY 114 (1979) (model victim's bill of rights). Because the victim's rights moveinent desires greater victim participation in the criminal justice system, it would be inconsistent for victim's rights activists simultaneously to argue that victims should be allowed to inaintain their privacy at trial. Trials are presumptively public, not private. But see infra note 176.

153. Marcus \& McMahon, supra note 107, at 1031-33.

154. See Estrich, supra note 1, at A25 ("[ $[$ ] is one thing for wounen to encourage one another to stand up and stand tall. It is another for a news organization to substitute its judgment for the victim's . . . ."); Christine Spolar, Debate on Publishing Names, WASH. PosT, Sept. 3, 1991, at H9 (quoting Susan Estrich saying "It may well be therapeutic for the individual woman to come outbut it ain't therapeutic when it's shoved down your throat.").

155. See Barbara Kantrowitz, Naming Names, NewsweEk, Apr. 29, 1991, at 26.

156. One newspaper article cited the following reasons for rape victims' fear of public disclosure: the fear that their private hives will be investigated; the fear that release of their identity will invite sexual attacks by other rapists; and the fear that they, not their attackers, will be put on trial. Emily Sachar, Naming Rape Victim Irks Advocates, NewSDAY, Apr. 18, 1991, at 119 (quoting Margie Metsch, program coordinator of Coluınbia University's Sexual Assault Awareness Program, and Louise Kindley, social worker at St. Luke's Roosevelt Hospital Rape Intervention Program); see also Dierdre Carmody, News Media's Use of Accuser's Name Is Debated, N.Y. Times, Apr. 18, 1991, at A22 (quoting Anne Seyınour, director of coinununications at the National Victim Center, as saying: "If you want to seriously reduce the number of men and women who come forth and report cases of rape to the authorities, just publish and broadeast their names and addresses in the inedia."). 
advocate] or my secretary."157 In a stinging critique of the media's practice of interviewing and scrutinizing a rape victim's credibility, Katha Pollitt recently wrote that the "chief cliaracteristic" of the system's treatment of rape is that "it puts genuine rape victims (98 percent of complainants) through such an ordeal, with so little hope of justice, that most (90 percent, according to Time) don't even report the crime. . . . As a justice-achieving systein, our approach to rape is a spectacular failure, but as a victim-deterrent system it works extreinely well."158

The foregoing reasons, if valid, would offer coinpelling arguments for protecting a rape victim's confidentiality. On the other side of the issue, lowever, commentators have called the government and inedia's pohicy of withholding rape victims' names paternalistic. ${ }^{159}$ Nadine Strossen has argued that "if we are ever to get beyond the situation where rape is seen as stigmatizing, where the victim is seen as 'dannaged goods,' then we have to stop mythologizing it and treating it as soine kind of special crime." 160 Furthermore, defense advocates have argued that it is unfair to publish the alleged assailant's naine but not to publish the alleged victim's name. Sucli protection heiglitens the stigma attached to being an accused rapist, thereby chipping away at the accused's presumption of innocence. ${ }^{161}$ Sucl protection functions as a validation of the victiln's story ${ }^{162}$ and also allows the victim to be an "anonymous accuser"-einpowered to dainage permanently the accused's pubhic reputation without having to reveal his own identity. ${ }^{163}$ Alan Dershowitz recently wrote

157. Estrich, supra note 1, at A25.

158. Katha Pollitt, Pollitt Replies, Nation, Sept. 9, 1991, at 250, 280. This argument can be critiqued by notimg that rape is drastically underreported even though the media have a general policy of not publishing the names of rape victims. See Nightline, supra note 123 (Nadine Strossen, President of the ACLU, speaking).

Many other crimes are underreported, but victin advocates do not cite fear of publicity as a reason for the gross underreporting of non-sexual crimes. Instead, the reasons victims typically give for not reporting a criminal incident are that they liave no faith in the system to provide a solution, they hold the police in low esteem, they think they lave insufficient evidence, they think the incident was too insignificant to inerit official attention, they are confused by the system, they fear retaliation, or they want to cut their losses and try to forget about the incident. See MorTon BARD \& DAWN Sungrex, The Crime Victim's Book 106-07 (1979); RoBert Elias, THe Politics of VictimiZATION: VICTIMS, VICTTMOLOOX, AND HUMAN RigHTS 135 (1986); HAGAN, supra note 75, at 19.

159. See Case May Shift Views on Naming Alleged Rape Victims, Seattle Times, Apr. 17, 1991, at A6; Richard Cohen, Doublc Standards on Rape Charges, WASH. Post, Apr. 18, 1991, at A21 ("I]f rape's indelible stigma is ever to fade, the press has to stop being complicitous in perpetuating the sexist aura that surrounds it. ... Publish the names.").

160. See Nightline, supra note 123.

161. See Cohen, supra note 159 ("II]f rape carries a certain stigma for the victim, it often does for the accused as well. With very few exceptions (matricide, child abuse), I can think of no more mortifying an aceusation.").

162. See Case May Shift Views on Naming Alleged Rape Victims, supra note 159.

163. See Nightline, supra note 123 (Nadine Strossen speaking). 
that the press's lopsided reporting policy is particularly unfair in rape cases because "false charges of rape are more frequent than false charges of any other serious crime." 164

It is important to emphasize at this point that the issue of the harm that results from publishing a rape victim's name is analytically distinct from the precise concern of this Note, which is whether the names should be disclosed to the press. Routine disclosure of a victim's name does not automatically result in the publication of that victim's name. Even newspapers that have poticies of interviewing crime victims and publishing their names in non-rape crimes do not publish the name of every victim in every crime. Metropohtan papers typically have space to report ouly the most serious crimes and will write stories about only the most egregious instances. ${ }^{165}$ Editors are not required to pubhsh victims' names and can exercise discretion not to publish the name when the circumstances call for such discretion. ${ }^{166}$ Most commentators addressing the harmful effects of publication have ignored the distimction between disclosure and publication, assuming that "routine disclosure" of a victim's name will automatically lead to the routine publication of that name. ${ }^{167}$ This is not a logical assumption, nor is it supported by the policy and practice of most media organizations in this country. ${ }^{168}$ In fact, the media in most states currently have access to the identities of rape victims but choose, in almost every case, not to pubhish the victims' identities. ${ }^{169}$ The media organizations that reported the name of the alleged victim in the William Kennedy Sumth rape case drew tremendous

164. Alan M. Dershowitz, Off the Mark, NATION, Sept. 9, 1991, at 250 ("According to the most recent authoritative statistics, 8.4 percent of reported rapes turn out to be false. This translates to more than 8,000 each year. This percentage is more than twice as high as for any other serious crime.").

165. Telephone Interview with Fred Barbash, supra note 117.

166. Telephone Interview with Karen Dillon, supra note 113 (stating that the Sarasota HeraldTribune has such a policy of editor discretion).

167. For example, Marcus and McMahon advocate restricting disclosure of the victim's name, but only discuss harm to the victim that resnlts from the publication of a victim's name. See Marcus \& McMahon, supra note 107, at 1031-33.

168. See Case May Shift Views on Naming Alleged Rape Victims, supra note 159, at A6 ("In the 1970 s, virtually all the nation's newspapers stopped publishing the names of alleged rape victims ... so that the alleged victims would not have to bear what was perceived as the added humiliation of public scrutiny.").

169. Although the New York Times generally does not publish the names of rape victims, it broke with its policy by publishing the name of the alleged victim of the William Kennedy Snrith rape. The Globe (a supermarket tabloid) and NBC had already published and broadcasted the victim's name. Howard Kurtz et al., NBC Identifies Woman in Florida Rape Probe; Network Breaks with Common Media Policy, WASH. Post, Apr. 17, 1991, at A3. Subsequently, the Des Moines Register, the San Francisco Chronicle, the Denver Post, the Fort-Worth Star-Telegram, and the Louisville Courier-Journal named the victim. Carmody, supra note 156, at A22. 
criticism from the public and other media. ${ }^{170}$ The public reaction to this incident indicates that the media will probably not soon change their policy of respecting the privacy of rape victims who desire to remain anonymous.

Assuming that the media will continue to respond to overwhelming public sentiment to not publisl rape victims' naines, then the argument that publication of a victim's name will harm that victim is not a coinpelling reason to keep the victim's name confidential at the investigative stage of a criminal matter. Even if the media does cliange its policy, the government's interest in protecting a crime victim's privacy is, ultimately, outweighed by the threat of sucli protection to the integrity of the criminal justice systen.

3. The Integrity of the Criminal Justice System. To determine whetler the government lias a compelling reason to withhold victims' identities, the victim's privacy interest slould be balanced against the competing imterests of the public, the suspect, and the criminal justice system. The public's primary interest im the criminal justice system at the investigative stage lies in encouraging the press to supervise the workings of that system to protect against state abuses of power. To this end, the victim's identity is significant information. ${ }^{171}$

The suspect or arrestee's interest in disclosure of the victim's identity at the investigative stage is one of basic fairness. It is unfair to protect the victim's naine when the suspect's is disclosed to the inedia. ${ }^{172}$ Furthermore, the accused criminal is in a far more vuhierable position thran is the accusing victim. The accused must submit to the coercive powers of the state and stands to lose the privileges of freedom. At the very least, the accused will suffer from the lasting public stigma of having been an accused criminal. It is ouly fair that a victim who is willing to subject a person to the ordeal of a criminal trial be willing to stand publicly by his accusations.

Moreover, the integrity of the criminal justice system is at stake. The modern system is founded on the notion of public access. It cannot accominodate the interests of participants in the system who merely desire to protect their privacy without compromising the most fundamental clieck on the fairness of the system - the public's responsibility to act as

170. See supra note 1.

171. See supra text accompanying notes $122-31$.

172. See supra text accompanying notes 161-64. 
overseer. ${ }^{173}$ Chipping away at public access to information about criminal investigations will only lead to greater goverimient secrecy, greater abuse of power, and less public confidence in an already sliaky systein. In theory, the interests represented at the investigative stage of the criminal inatter are fairly evenly balanced. The victim has an ascertainableif nebulous-privacy interest that is offset by the suspect's interest in fair treatinent. The balance is tipped, however, by the strengtli of the pubhic's interest in access to information about criminal investigations. The integrity of the system depends on tle public playing an active role in ensuring that the system is operating fairly.

This Note urges, therefore, that state and federal governments should not attempt to restrict access to victims' names inerely to protect a victim's privacy interests. If a government does try to restrict access to victims' identities for privacy reasons and this restriction is challenged by the public, a court slould not find that the government has asserted a "compelling interest."

\section{The Public's Right of Access to A Victim's Identity at the Pre-Trial and Trial Stages of a Criminal MATTER}

Based on the Globe and Press-Enterprise cases, the public has a right of access to pre-trial and trial proceedings. ${ }^{174}$ Because this right of access extends to information revealed at such proceedings, a victim's identity, if revealed at trial, becomes part of the public record. ${ }^{175}$ Even thougli criminal proccedings are presumptively open, a significant number of states have enacted legislation that restricts public access to identifying information about a victim at pre-trial and trial hearings. ${ }^{176}$

173. This Note does not suggest that the privacy interests of non-participating third parties-for example, third parties whose names appear on wiretap transcripts-should not be protected. See infra note 210 .

174. See supra text accoinpanying notes 37-43.

175. See, e.g., In re New York Times Co., 828 F.2d 110, 114 (2d Cir. 1987) (qualified First Amendinent right of access extends to written documents subımitted in pretrial proceedings); see also supra note 44 and accompanying text.

176. Some states only protect a victim's identity until the preliminary stages of the trial. See, e.g., OHIO REV. CODE ANN. $§ 2907.11$ (Baldwin 1989) ("Upon the request of the victim or offender [in a prosection for sexual offense], the judge ... . shall order that the names of the victim and offender and the details of the alleged offense ... . be suppressed until the preliminary hearing, the accused is arraigned ..., the charge is dismissed, or the case is otherwise concluded, whichever occurs first.").

Other states exphicitly protect the victim's identity through the trial. See, e.g., Victims' Rights Act of 1991, ch. 57, §13, 1991 Alaska Sess. Law Service (West) (to be codified at ALASKa STAT. $\S 12.61 .140$ ) (identity of a sexual victim is not a matter of public record; victim inay use initials in all transcripts of otherwise open proceedings, see supra note 6 and accompanying text); Cal. PENAL CODE $\S 1102.7$ (West 1985) (prosecution may be required to give defense counsel, but not defendant, 
Under the Globe test, the question remains whether the state can restrict access to a victim's identity at this stage by asserting a compelling interest im protecting that victim's privacy, and whether such a restriction can be accomplished in a narrowly tailored manner. ${ }^{177}$ To answer this question, it is necessary to examine three issues: the precise scope of the victim's privacy imterest at a criminal proceeding; how that imterest can be narrowly protected; and whether that interest is coinpelling. Part

victim's identity); CONN. GEN. STAT. ANN. § 54-86e (West 1985) (entitling victims of sexual assault to confidentiality during court proceedings); FLA. STAT. ANN. \& 794.03 (West 1976) (It is unlawful to "print, publish or broadcast, or cause or allow to be printed, publislied, or broadcast" a rape victim's name or other identifying information. But see Doe v. Sarasota-Bradenton Fla. Television Co., 436 So. $2 \mathrm{~d} 328$ (Fla. 1988) (holding the statute inapplicable where television station obtained the publislied name from a public trial)); GA. CODE ANN. \$ 16-6-23 (Michie 1988) (1naking it a misdeineanor to publisl victim's name, unless obtained froin official court records); ME. REV. STAT. ANN. tit. 19, $\S 766-A$, tit. 22, $\S 4008$ (West Supp. 1990) (protecting identity of minor victims of sexual crimes); MAss. ANN. LAws cl. 265, § 24C (Law. Co-op. Supp. 1991) (witlliolding identities of sexual assault victims froin public except with judge's approval); Act of July 1, 1991, ch. 251, § 1, 1991 Sess. Law News of N.Y. (McKinney) (to be codified at N.Y. Civ. RuGHTS LAw § 50-b) (disallowing public relcase of any "report, paper, picture, photograpl, court file or other doeument" identifying a victim of a sexual offense); S.C. CODE ANN. \& 16-3-730 (Law. Co-op. 1985) (making it a misdemeanor to publish victim's name, unless obtained from official court records); S.D. CoDIFIED LAwS ANN. \$ 23A-6-22 (1987) (allowing victim or aceused in sexual assault proceedings to request that their identities be suppressed until case is concluded); TEX. CRIM. Proc. CODE ANN. $§ 57.02$ (b) (West Supp. 1991) ("A victim [of a sexual offense] may choose a pseudonym to be used instead of the victim's name to designate the victim in all public files and records concerning the offense, includimg pohice summary reports, press relcases, and records of judicial proceedings.").

Other states protect identifying infornation other than the victim's name, such as teleplione numbers, addresses, or places of employment, from disclosure during proceedings or froin disclosure in court records. See, e.g., ARIz. R. CRIM. Proc. 39(b)(8) (Supp. 1990) ("The riglit to require the prosecutor to withhold, during discovery and other proceedings, the lome address of the victim [and] the name of the victim's einployer" is guaranteed to the victim, as well as the riglit to demand that such addresses "sliall not be conveyed to the defendant."); IDAHO CODE $§ 19-5306(2)$ (1987 \& Supp. 1991) (kecping victiin's address confidential); ILL. ANN. STAT. ch. 40, para. 2312-3 (SmitlHurd Supp. 1991) (allowing victims of doinestic violence to keep their addresses off court rccords if it would protect their safety); MD. CTS. \& JUD. PRoc. CODE ANN. § 9-501 (1989) (authorizing judge to withhold victim address and teleplione number from defense if irrelevant to case); MINN. STAT. ANN. § 611A.035 (West 1987) (permitting victim not to give address in open court); NEV. REV. STAT. ANN. $§ 48.071$ (Michie 1986) (requiring prosecution to witlliold telephone number and address of any sexual assault victim from defendant); N.M. STAT. ANN. § 31-24-5 (Michie 1984) (allowing victim not to give telephone number or loone or busmess address in sworn testimony); N.D. CENT. CODE $\S 12.1-34(10)$ (Supp. 1991) (penmitting victims and witnesses to not testify to identifying infornation except name); OR. REV. STAT. $\S 135.970$ (1990) (preventing disclosure of victim's address and phone number to defendant); WIS. STAT. ANN. $\$ 904.13$ (West Supp. 1991) (permitting victims not to give address or place of employment when they testify unless deeined relevant); see also Guidelines for Victim and Witness Assistance, D.C. Op. Att'y Gen. (July 9, 1983) reprinted in VICTIM RighTs, supra note 93, at 291 ("Departinent officials should avoid, to the extent possible, disclosing the addresses of victims and witnesses. Prosecutors should resist attempts by the defense to obtain the addresses of victims and witnesses.").

177. See supra text aecompanying notes 49-58. 
III analyzes the victim's privacy interest and concludes that a victim retains an interest in keeping his name out of the public record. To determine whether this interest is compelling, Part III next compares the victim's privacy interest to the interests of other participants that have been declared coinpelling and concludes that the victim's privacy imterest is not as significant.

\section{A. Does the Victim Have a Privacy Interest That Can Be Protected at a Criminal Proceeding?}

It is possible to argue that the victim who decides to invoke the criminal justice system waives his right to privacy-that once he reports a crime he abdicates control over the dissemination of the facts of the crime and over the dissemination of his identity in conjunction with those facts. This argument rests on the assumption that the victim's interests in a criminal matter are indistinguishable from the public's interests once pre-trial and trial proceedings begin. ${ }^{178}$ In other words, the public's interest in overseeing the fair administration of criminal justice and in protecting against state abuses of power belongs to the victim in precisely the saine way that it belongs to any other ineinber of the public. Under this view, a victim's interest in maintaining his privacy could never supersede the public's interest in overseeing criminal justice because the victim's privacy interest would only be legitimate to the extent that it did not conflict with the pubhic's interest. 179 By protecting the victim's privacy interests over the public's interest in overseeing the criminal justice system, the government actually would be undermining the victim's interests in seeing that justice is enacted.

If a victim's decision to participate in the criminal justice system effectuated a coinplete waiver of his privacy interests, then a victim would no longer have an interest that could be protected by restricting access to his identity. ${ }^{180}$ However, a brief examination of civil law cases reveals that participants in the criminal justicc system, including victims, retain a privacy interest for some civil law purposes.

Defanation cases show, for example, that victims and other participants in the criminal justice system do not become public figures even though they have been involved in criminal proceedings. The leading

178. See ZiEgenHAGEN, supra note 70; see also supra notes 77-78 and accompanying text (discussing a victim's role in the criminal justice systein).

179. This view is not refuted by juror anonymity cases. See infra notes 202-04 and accompanying text.

180. Case law shows that the state clearly has a compelling interest in protecting the anonymity of any participant in a trial whose life or safety has been threatened. See infra text accounpanying notes 201, 203, 207. Thus, a victim who is in physical danger would also be granted anonymity at trial. 
case in this area is Time, Inc. v. Firestone, ${ }^{181}$ in which the Supreane Court held that a party to a divorce proceeding was not a "public figure" for the purposes of defamation law. The Firestone Court applied a two-part test to measure whether the litigant had waived lier privacy interest, asking first whether the litigant was involved in a "public controversy," and second whether the hitigant had "freely [chosen] to publicize issues" about her marriage. ${ }^{182}$ The plight of the party seeking a divorce in Firestone is similar to that of a victim in a criminal trial. Both are required to appear in court-are "drawn into a public forum largely against their will"-because of a legal action that neither sought. ${ }^{183}$ Victims, defendants, and witnesses in criminal matters have sought damages under defamation law based on the standard establislied in Firestone. ${ }^{184}$

In contrast to their success in defamation cases, victims have not been successful in seeking damages agamst newspapers that publish facts about a crime relating to the victim. Although no court has held that a criminal trial is per se newsworthy, the public nature of a criminal inatter weighs heavily in favor of the press in a suit for invasion of privacy. In Ross v. Midwest Communications, Inc., ${ }^{185}$ for example, the Fifth Circuit held that a newspaper was entitled to publish details about a rape because the rape trial liad been a inatter of "legitimate public conceru," even though the published details involved private facts about the victim's life. ${ }^{186}$ The Ross court specifically considered and rejected the possibility that the victim could base a tort action on the newspaper's use of ler identity in coimection with the details of the rape, concluding that the public's legitimate concern in the details of the crime is "inseparable froin" its interest in the connection between the details and the victim. ${ }^{187}$

\footnotetext{
181. 424 U.S. 448 (1976).

182. Id. at 454 (following Gertz v. Robert Welch, Inc., 418 U.S. 323 (1974)).

183. See id. at 457.

184. See, e.g., Mills v. Kingsport Times-News, 475 F. Supp. 1005, 1009 (1979) (holding that defendant in a murder case did not become a public figure simply by being involved in a newsworthy event); Schultz v. Reader's Digest Ass'n, 468 F. Supp. 551, 558-59 (1979) (holding that witness in the Jimmy Hoffa inurder case did not voluntarily inject himself into the Hoffa affair and thus was not a public figure even though Hoffa's disappearance was a public controversy); Jacobson v. Rochester Commurications, 410 N.W.2d 830, 836 (Minn. 1987) (holding that defendant in an arson prosecution did not become a public figure even though he granted one interview to a newspaper after his conviction was reversed). But see Street v. National Broadcasting Co., 645 F.2d 1227, 123435 (6tl Cir. 1981) (determining that victim and primary witness in the Scottsboro rape trials forfeited her privacy because sle had " 'voluntarily' thrust herself in the forefront of the public controversy" by giving press conferences in which sle "aggressively promoted her version of the case").

185. 870 F.2d 271 (5tll Cir. 1989).

186. See id. at 275.

187. See id. at 274. Even witnesses participating in the Federal Witness Protection Progran (FWPP), 18 U.S.C. \& 3521 (1988), which explicitly protects the identities of witnesses, do not necessarily retain a privacy interest in their identities for an invasion of privacy action. In Capra v.
} 
State governments are also precluded from authorizing civil sanctions against newspapers that publish truthful information appearing in court records. In Cox Broadcasting Corp. v. Cohn, ${ }^{188}$ the Supreme Court invalidated a civil damages award against a television station, holding that a state "may not impose sanctions on the pubhication of truthful information contained in official Court records open to public inspection."189 In Florida Star v. B.J.F., ${ }^{190}$ the Supreine Court followed Cox Broadcasting to hold that a state could not punish a newspaper for pubhishing a victim's name if the victim's identity had been released to the inedia accidentally, notwithstanding the state's strict policy of denying access to victims' identities at the investigative stage. ${ }^{191}$ The clear message of these cases is that a victim retains virtually no privacy interest, except for defaination purposes, once his naine is placed upon the public record or otherwise officially released into the public doinain.

Cox Broadcasting and Florida Star suggest that the victim's privacy interest exists, if at all, in keeping his identity out of the public record of a criminal proceeding, ${ }^{192}$ or in restricting access to records that contain

Thoroughbred Racing Ass'n, 787 F.2d 463 (9th Cir. 1986), the Ninth Circuit found that a newspaper that published the names of witnesses participating in the FWPP was not per se hable for an invasion of privacy; participation was only a factor in determining whether the witnesses' names were newsworthy. See id. at 465 .

188. 420 U.S. 469 (1975).

189. Id. at 495. The Court left open the issue of whether the state could punish newspapers if they obtained their information illegally.

In several older cases, state courts upheld state privacy statutes that punished newspapers for publishing rape victims' names. In State v. Evjue, 33 N.W.2d 305 (Wis. 1948), for example, the Wisconsin Suprene Court found a statute punishing the publication of a rape victin's identity to be constitutionally valid, reasounig "that there is a minimun of social value" (i.e., newsworthiness) in publishing such information. Id. at 312; see also Nappier v. Jefferson Standard Life Ins. Co., 322 F.2d 502, 505 (4th Cir. 1963) (construing South Carolina statute to provide a private cause of action against newspapers that publish the names of rape victims). After Cox Broadcasting, the statnte upheld in Evjue could only be valid if it were applied to media that obtained a victin's name illegally. See Cox, 420 U.S. at $495-96$.

190. 491 U.S. 524 (1989).

191. See id. at 541. The Court's comments should only be construed to apply to the investigative stage of a criminal inatter because the case involved a newspaper that acquired a victim's identity at the investigative stage-when the assailant was still at large. See id. at 526-28; see also supra notes 82-84 (discussing the Florida Star decision).

192. The privacy interest in keeping one's name out of a pubic record or in restricting access to the public record is much narrower than the privacy interest asserted in Florida Star. The state in Florida Star was attenpting to protect the victim's privacy in the sense of controlling the public association of the victim's name with the facts of the crime, or of the public disclosure of enbarrassing facts. The Supreme Court stated that the Florida statute prohibiting the publication of a rape victim's name did not "satisfactorily accoinplis[h] its stated purpose" of protecting the victim's privacy becanse it was underinclusive; punishing the inedia for publication would not prevent the public dissemination of the victim's name when a "backyard gossip" could tell 50 people about the incident without being subject to the statute's sanction. See id. at 540-41. It is donbtful whether any statute could protect such a broad interest without being an undue restraint on freedom of speech. 
his identity. ${ }^{193}$ The Cox Broadcasting Court stated, in dictuin, that "[i]f there are privacy interests to be protected in judicial proceedings, the States inust respond by ineans which avoid public documentation or other exposure of private information." 194 The Court had previously reinarked that "[b]y placing the information in the public domam on official court records, the State inust be presumed to have concluded that the public interest was thereby being served."195 These statements imply that the state is entitled to keep a victim's name out of a court record if there is a coinpelling privacy interest to be protected.

A court or government could restrict access to a victim's name at the pre-trial and trial stages of a criminal matter in any number of ways. It could prevent public access to court records containing the viction's name; it could release court records with the name redacted; or it could assign a pseudonym that would designate the victim in all court records and in the actual proceedings. ${ }^{196}$ Any of these would be a narrowly drawn and effective inethod of keeping the victim's name off the public record, or of controlling the pubhic's access to the victim's identity through official sources. To be fully effective, this action would have to be supported by a police policy of redacting victim's names from coinplaints and incident reports. Furthermore, to avoid overbreadth, the protection could only extend if the victim affirmatively requested it.

\section{B. Is the Victim's Privacy Interest Compelling?}

Even if a court or government orders a narrowly tailored restriction on access to a victim's identity, this restriction constitutes an imfringeinent on the public's right of access to that information. Under Globe, such a restriction would ouly be.valid if the government could assert a compelling reason for the restriction.

The Globe Court gave no guidance about which interests are sufficiently compelling to warrant restrictions on public access, except that a

193. It is clear that a statute restricting access to certain public records can be narrowly designed so that it restricts access without violating constitutional considerations. See supra notes 85-88, 14246 and accompanying discussion of FOIA. The Supreme Court's interpretation of FOIA also suggests that a crime victim's privacy interest is lodged, if anywhere, in the public records that contain the victim's name, and that the victim's privacy interest in those records can be protected by restricting access to them. See supra notes 142-46 and accompanying text for further discussion of this suggestion.

194. Cox Broadcasting, 420 U.S. at 496.

195. Id. at 495. This dictum implies that a victim would not be allowed to protect his identity from public disclosure if the state had established a policy of placing victims' names on the public record.

196. See supra note 176 and aecompanying text. 
"compelling interest" need not be a constitutionally protected interest. ${ }^{197}$ There are no reported cases in which the media have sued to gain access to a victim's identity. To determine whether the government has a compelling interest in keeping a victim's nane out of the public record, it is thus useful to examine otlier interests that the courts liave deemed compelling and compare them to the victim's interest. This Section will survey First and Sixth Amendment ${ }^{198}$ cases in which the government successfully asserted a compelling interest in protectimg a participanteither witness, juror, or victim -at a criminal proceeding. If the victim has interests comparable to an informant's, witness's, or juror's at trial, ${ }^{199}$ then a victim would deserve anonymity under the saine conditions that other participants are accorded anonymity. This Section concludes that the victim's interest, although significant, does not compel restricted access to the victim's identity at trial.

197. See Globe Newspaper Co. v. Superior Court, 457 U.S. 596, 606 (1982). In his Richmond Newspapers concurrence, Justice Stewart wrote that interests besides "constitutional considerations" could justify restrictions on public access to a trial: "[T] he sensibilities of a youthful prosecution witness, for example, might justify [the exclusion of the public from at least some segments of] a criminal trial for rape, so long as the defendant's Sixth Amendment right to a public trial were not impaired." Richmond Newspapers Inc., v. Virginia, 448 U.S. 555, 600 n.5 (1980) (Stewart, J., concurring). If this dictum were followed, then a victim's privacy interest need not be a coustitutionally protected interest to justify limitations on public access. It should be noted that Justice Stevens did not advocate keeping the victim's identity confidential.

198. Although there are few cases in which the public's right of access has been restricted by a compelling interest, see supra text accoinpanying notes 53-57, there is a large body of Sixth Amendment jurisprudence in which public access has been restricted at trial over the defendant's objection. Although these Sixth Amendment cases are not direetly on point, they are useful to illustrate the types of interests that courts have deeined compelling at trial.

Currently, Sixth Amendment public trial jurisprudence and First Amendinent right of access analysis employ nearly congruent tests to measure whether public access to criminal proceedings can be restricted. In Waller v. Georgia, 467 U.S. 39 (1984), the Suprene Court ruled that closure of a suppression hearing over a defendant's Sixth Amendment objection is only appropriate if the state can "mect the tests set out in Press-Enterprise [ $]$ ] and its predccessors." Id. at 47. In other words, the defendant's presumptive right to a public trial can only be rebutted if "the party seeking to close the hearing [advances] an overriding interest that is likely to be prejudiced, the closure [is] no broader than necessary to protect that interest, the trial court [considered] reasonable alternatives to closing the proceeding, and [has made] findings adequate to support the closure." Id. at 48.

The holding in Waller indicates that the state's "overriding interest" for closing a proceeding over the defendant's objection must be at least as compelling as an interest that suffices to close a hearing over the public's objection, leaving open the possibility that the Sixth Amendinent test might be stricter than the First Amendinent test: "[T]he explicit Sixth Amendinent right of the accused is no less protective of a public trial than the implicit First Amendment right of the press and public." Id. at 46. For the purposes of this Note, the Waller test means that a privacy interest sufficient to restrict access to information revealed at a public proceeding over the defendant's objeetion will certainly suffice to restrict access over the public's objection.

199. The prevailing view of a victim's role in a criminal trial is that a victim is comparable to any other witness. The victim is not a party to the action, which exists between the defendant and the state, and cannot be granted any special status as a victim because to do so would violate the defendant's presumption of imocence. See ZIEgenhaGeN, supra note 70, at 76. It cannot be denied, 
1. Restrictions on Access to Identifying Information in a Criminal Proceeding. In a limited number of First and Sixth Amendment cases, the government has been permitted to restrict public access to identifying information revealed at a criminal proceedimg. The government's interests in obtaining such restrictions have been more urgent tlian to protect a privacy interest.

Courts have uplield the government's ability to conceal the identity of an undercover agent against Sixth Amendment challenges. ${ }^{200}$ The state was found to liave a coinpelling interest in safeguarding the agent's life and in preserving his future usefulness. This interest justified concealing the agent's identity and excluding the public from a trial for the limited period while the agent testified. ${ }^{201}$ The state cannot assert either of these interests-protecting life or preserving future usefuhiess-in concealing a victim's identity for privacy reasons.

Courts have also upheld against First and Sixth Amendment clrallenges a trial court's decision to have an anonymous jury. ${ }^{202}$ Anonymous juries are sometimes ordered in widely publicized criminal trials that involve defendants with proven connections to organized crimie. In such cases, the jurors' identities are concealed equally from the public, the prosecutor, and the defendant. The government's interest im requesting an anonyınous jury is to protect the jury against possible death threats,

however, that a victim's role in a criminal matter assumes a more central status than that of witness or informant because the victim was the recipient of the action in dispute and the justification for the social action taken against the defendant. Id. at 69 . Under this view, a victim's identity is of central concern to a criminal matter-comparable even to the identity of the defendant-and the victim, like the defendant, would not have the right to remain anonymous. See Richmond Newspapers, 448 U.S. at 580 (defendant has no right to a private trial); Gannett Co. v. DePasquale, 443 U.S. 368, 382 (1979) (defendant cannot demand a private trial).

200. These cases are brought under the Sixth Amendment's Public Trial Clause, U.S. ConsT. alnend. VI.

201. See, e.g., United States ex rel. Lloyd v. Vincent, 520 F.2d 1272, 1274-75 (2d Cir. 1975) ("[E]xposure in a public courtroom would not only imperil the agent but would render him useless for any further investigative activities."); Boyd v. Lefevre, 519 F. Supp. 629, 633-34 (E.D.N.Y. 1981) (holding closure of courtrooin during one part of pre-trial hearing proper to avoid public exposure that would imperil undercover agent personally and impair his usefulness as confidential investigator).

202. Defendants have objected to anonymous juries because they encroach on the defendant's presumption of innocence and because withholding a juror's identity prevents the defendant from selecting a fair and impartial jury based on meaningful selection criteria. Regardless of these objections, courts have held that meaningful selection criteria do not necessarily rely upon the jurors' identities. The trial court in United States v. Edmond, 730 F. Supp. 1144 (D.D.C. 1990), addressed this issue when it ruled that an anonymous jury was warranted im the trial of a notorious Washington D.C. drug dealer. First, the court noted that "it is well-established that attorneys do not have the right to learn everything about a prospective juror." Id. at 1148 . Second, the court noted that the defense attorneys had not shown that knowledge of the jurors' names, addresses, and places of employment was material to any issue that might arise at trial. Further, both sides of the case would be "equally in the dark" about jurors' identity. See id. at 1149 n.11. 
extortion, or bias from media exposure. ${ }^{203}$ These cases illustrate that the defendant's, public's, and prosecutor's interests in gaining access to jurors' identities are, in some circumstances, outweighed by the jurors' interests ${ }^{204}$ in personal safety and im remaining impartial.

These juror anonymity cases are not comparable to cases in which the government would petition for victim anonymity. First of all, jurors do not play a coinparable role to the victim at trial because jurors are factfinders, not witnesses. Second, the government's interest in keeping tlie victim's name off the public record is less urgent than its interest in protecting jurors. There is no doubt that disclosure of a victim's name can lead to anguishing personal humiliation should the press decide to pubhish tliat name. However, the risk of disclosure leading to embarrassing publication is less serious than the risk represented by submitting a jury to tlie perils of extortion or deatli threats. Even if no jurors are physically harmed, extortion and threats can lead to a biased jury, which threatens the integrity of the trial. The victim's privacy interest, although substantial, does not rise to that level.

As a final example of permissible restrictions on public access, courts liave uplield against Sixth Amendment challenges the government's ability to protect the confidentiality of a non-testifying informant. ${ }^{205}$ In these cases, the government's interest in non-disclosure is

203. See, e.g., United States v. Tutino, 883 F.2d 1125, 1132 (2d Cir. 1989) (upholding anonymous jury over defendant's Sixth Amendment challenge); Gannett Co. v. State, 571 A.2d 735 (Del. 1989) (upholding anonymous jury over inedia's First Amendment challenge). In Tutino, the governInent succeeded in obtaining an anonymous jury after it offered five justifications for requesting an anonymous jury: (1) the defeudant faced serious penalties and was therefore more likely to bribe the jury; (2) the defendant had tried to tamper with a jury in a previous trial; (3) the defendant was a known (previously convicted) meinber of organized crime; (4) the defendant had a prior extortion conviction; and (5) the jury needed to be protected from the media. Tutino, 883 F.2d at 1132. The Second Circuit upheld the anonymous jury because the government had made "substantial" showings of the five factors, because the trial judge instructed the jurors that anonymity was "in no way unusual," and because the judge conducted an extensive and meaningful voir dire that covered niany topics except jurors' names, addresses, and places of employment. See id. at 1132-33. But see In re Globe Newspaper, 920 F.2d 88, 92-93 (1st Cir. 1990) (holding that jurors' names and addresses must be released to the public in the absence of specific findings on why they should not); United States $v$. Melendez, 743 F. Supp. 134, 138-39 (E.D.N.Y. 1990) (stating that jurors were entitled to soine protection but not anonymity in ease involving no prior atteınpts at juror tampering and little media coverage).

204. Even though the state petitions for juror anonymity, the interests it asserts properly belong to the jurors.

205. These challenges are brought under the Conupulsory Process Clause of the Sixth Amendnient, U.S. CONST. amend. VI. Informant cases are decided under a standard set forth in Roviaro v. United States, 353 U.S. 53 (1957), in which the Court granted a defendant access to the identity of a confidential informant. Because the identity of a confidential government source is protected at trial by governnient privilege, the defendant must overcone the presumption of confidentiality by showing that disclosure would be "relevant and helpful" to his defense or that it is "essential to a fair 
balanced against other factors such as the level of the informant's involvement in the criminal activity and the helpfulness of disclosure to the defendant's case. ${ }^{206}$ Typically, only two government interests-those of promoting the free flow of information and of protecting an informant's safety-have been approved by courts applying this test. ${ }^{207}$ In United States v. Herrero, ${ }^{208}$ however, the Seventh Circuit held that the governinent's promise of confidentiality, in furtherance of law enforceinent activity, suffices to sustain the privilege. ${ }^{209}$

Ostensibly, Herrero shows that the identity of a non-testifying victim, like the identity of a non-testifying informant, can be kept froin the defendant-and by extension, from the public-if the government inakes a promise of confidentiality to the victim. It is unlikely, however, that the reasoning asserted in Herrero can be apphied to protect a victim's anonymity at trial. A defendant would be able to inake a strong showing that the informant/victim was centrally involved in the criminal activity, and furthermore that the informant/victim's identity is essential to estabhishing the defendant's case. Thus, informant cases do not offer a rationale for protecting a victim's identity at trial..$^{210}$

determination of a cause." Id. at 60-61. The defendant's specific interests in obtaining the informant's identity are then balanced against the government's privilege. See id. at 64. In Roviaro, the Supreme Court held that the defendant had met this burden because the government's informant was the defendant's only material witness; thus, the informant's identity was essential to the defendant's ability to prepare his defense. Id. at 64-65; see also United States v. Feola, 651 F. Supp. 1068, 1139 (S.D.N.Y. 1987) (upholding confidentiality of informant's identity because defense did not meet its burden of showing that identity was essential to the defense).

206. See Urited States v. Singh, 922 F.2d 1169, 1172 (5th Cir. 1991).

207. In Roviaro, the government's purpose in withholding the informant's identity was to further effective law enforcement by encouraging citizens to report information about crime. The Court characterized the balancing of interests in Roviaro as between "the public interest in protecting the flow of information against the individual's right to prepare his defense." 353 U.S. at 62 . See also Urited States v. Rivera, 738 F. Supp. 1208, 1214 (N.D. Ind. 1990) (finding safety of confidential informant to be a factor im permitting government to protect confidentiality of informants at a suppression hearing).

208. 893 F.2d 1512 (7th Cir.), cert. denied, 110 S. Ct. 2623 (1990).

209. See id. at $1524-25$ ("[T] he government nced not make a threshold showing that reprisal or retaliation [against the informant] is likely ....") (citation omitted).

210. The Second Circuit has held that the privacy interests of imıocent third parties whose names appeared in a wiretap transcript might be sufficiently compelling to justify restricting public access in spite of a First Amendment challenge. In In re New York Times Co., 828 F.2d 110 (2d Cir. 1987), the government asked to seal motions submitted at a suppression hearing because they contained names of innocent third parties and private information about the defendants-i.e., information unrelated to the criminal inatter. Although the Second Circuit did not specifically find that the privacy interest at stake was "compelling" or a "higher value," it indicated as inuch by remanding the case with the instruction that the privacy interest should "weigh heavily in a court's balancing equation" in determining which parts of the inotion should remain sealed or be redacted. Id. at 116. The privacy interests of the innocent third parties in In re New York Times Co. are not entirely coinparable to a those of a victim. Although both parties have been thrust involuntarily into the criminal justice system, the third parties are entirely unconnected to the criminal matter in question 
In conclusion, courts have upheld government restrictions on public access to the identities of participants in a trial for the purposes of safeguarding a life or of protecting the fairness of the trial. Restricting access to identities is a drastic measure, evidenced by the seriousness of the interests asserted to justify it. Courts have upheld the confidentiality of non-participants in a trial to further law enforceinent or to protect a privacy interest, but they have only upheld the privacy interest when the person involved had no connection to the criminal matter in question. There are no cases in which the government has protected the identity of a participant at trial who is ccntrally involved in the criminal matter (i.e., the victim) for purely privacy reasons.

\section{Other Restrictions on Access Justified by Privacy Interests.} When the government asserts a privacy interest to restrict public access to a criminal proceeding, the government has typically been allowed to restrict access to the actual proceeding, but not to keep information out of the public record.211 A typical example occurred in United States ex rel. Latimore v. Sielaff, 212 in which a reviewing court upheld a rape conviction over the defendant's Sixth Amendment objection that the trial judge had cleared the court of spectators during the victim's testinnony. The trial judge asserted that he closed the trial to protect the victim's privacy and dignity: "Rape constitutes an intrusion upon areas of the

whereas the victim is centrally involved in the criminal inatter in question. Unlike a non-testifying informant, the third parties are not even participants in the criminal matter. The innocent third parties thus have a greater privacy interest than victims at trial. See also John Does I-V v. Pulitzer Publishing, 895 F.2d 460, 467 (8th Cir. 1990) (upholding confidentiality of identities of suspects for whom search warrants but no indictments had issued); United States v. Smith, 776 F.2d 1104, 1114 (3d Cir. 1985) (upholding confidentiality of identities of unindicted co-conspirators in a bill of particulars).

211. Partial or total closure of proceedings has also been allowed when the government asserts a compelling interests in protecting a witness from harm, see United States v. Hernandez, 608 F.2d 741, 747-48 (9th Cir. 1979) (holding that a trial judge properly excluded the public during the testimony of a lead witness who had received death threats against himself and his family); United States v. Eisner, 533 F.2d 987, 933 (6th Cir. 1976) (en banc) (finding that judge did not abuse discretion by excluding the public spectators (but not the press) during the testimony of a witness who was fearful of "the courtroom and the persons that might be in it"); in preserving an inipartial and functioning jury, see United States v. Edwards, 823 F.2d 111, 117 (5th Cir. 1987) (ruling that interest in preserving the jury justified excluding public from midtrial hearings on possible juror misconduct); or when the government or defendant asserts an interest in protecting the defendant's fair trial right, see Copley Press, Inc. v. Superior Court, 278 Cal. Rptr. 443, 450 (Ct. App. 1991) (holding that defendant's right to fair trial justified delayed release of questionnaires given to venirepersons in capital case); Cowles Publishing Co. v. Magistrate Court, 800 P.2d 640, 647 (Idalio 1990) (finding that defendant's right to fair trial justified exclusion of public from preliminary hearing).

212. 561 F.2d 691 (7th Cir. 1977). 
victim's life, both physical and psychological, to which our society attaches the deepest sense of privacy."213 The reviewing court found that the victim's privacy interest justified the trial judge's actions, but noted, significantly, that the press and all interested parties had been allowed to stay in the courtrooin during the victim's testimony. ${ }^{214}$ In other words, the victim's identity was not protected; instead, the courtroom was cleared to reduce the victim's ordeal of having to repeat her story in front of a large crowd. ${ }^{215}$

Based on their desire to protect witnesses froin embarrassinent and humiliation, courts have also protected the privacy interests of minor victims and witnesses by ordering total or partial closure of the courtrooin. ${ }^{216}$ In one interesting case, a trial judge issued a pre-trial order in which he agreed to allow unrestricted press access to the identities of minor victims in a child abuse case conditioned on the press's guarantee that it would not publish the names.217 The reviewing court approved of the order, noting that the trial court could, within its discretion, completely restrict access to the names because of the state's coinpelling interest in protecting the minor victims of sex crimes. ${ }^{218}$

Courts have frequently einployed a range of protective ineasures to prevent the public dissemination of private infornation that is uurelated to the criminal inatter at the proceeding. In Press-Enterprise $I^{219}$ for example, the trial judge closed the voir dire for a rape case, intending to protect the privacy interest of jurors who imight have highly personal answers to his questions. ${ }^{220}$ The Supreine Court indicated that such privacy interests imight be sufficiently compelling to warrant closure of voir

213. Id. at 694 .

214. See id. at 694; accord Geise v. United States, 262 F.2d 151 (9th Cir. 1958) (offering privacy rationale to uphold a rape conviction when thc courtroom had been closed to all spectators, except menibers of the bar and of the press, during testimony of complaining and other minor witnesses).

215. See also United States v. Galloway, 937 F.2d 542, 546 (10th Cir. 1991) (permitting partial closure of trial during testimony of conplaining witness only if trial judge makes specific findings that testifying in open court was likely to harm her); United States ex rel. Morgan v. Lane, $705 \mathrm{~F}$. Supp. 410, 412-14 (N.D. Ill. 1989) (holding that mitigation of ordeal to conplaining witness justified closure of trial to disinterested spectators during her testimony, but that press was allowed to stay).

216. See, e.g., Davis v. Reynolds, 890 F.2d 1105 (10th Cir. 1989). In Davis, the reviewing court found that "[t]he government clearly has a compelling interest in protecting youthful witnesses who are called upon to testify in cases involving sensitive and painful issues; those types of issues are very hikely to appear in cases involving alleged sexual offenses." Id. at 1110. The court held, however, that the trial court's action in clearing the entire court was inappropriate absent specific findings of a compelling interest. See id.

217. See In re V.V. Publishing Corp., 577 A.2d 412, 414 (N.J. 1990).

218. See id. at 417. The reviewing court also noted that the parents of nany of the alleged victims had agreed to allow their children to testify conditioned upon the state's guarantee of confdentiality. See id.

219. 464 U.S. 501 (1984).

220. See id. at 503. 
dire, ${ }^{221}$ but found that the judge had not made any specific findings to show that those imterests would in fact be threatened by an open hearing. 222 In dictum, the Court indicated that lower courts inust fashion a compromise between the privacy interests of the juror and the need for openness in the process. A trial judge could employ a range of protective measures-including delayed release of the voir dire transcript, releasing the transcript but omitting the juror's name, or sealing an entire portion of a transcript-to match the restriction on access to the level of the asserted privacy interest. ${ }^{223}$

Similarly, in Waller v. Georgia, ${ }^{224}$ the Court held that a trial judge had erred in closing a seven-day suppression hearing in which wiretapping evidence was revealed. The state's purpose for closing the suppression hearing was to prevent the public dissemination of private information contained in the wiretaps that was unrelated to the criminal matter. The Supreme Court found that "[u]nder certain circumstances, these [privacy] interests may well justify closing portions of a suppression hearing to the public," but closure was unjustified here because the trial judge did not make specific findings of necessity. ${ }^{225}$ The Court did not mdicate what circumstances would permit a privacy interest to justify closure of a suppression hearing, but did not foreclose that possibility.

The First and Sixth Amendment cases just discussed reveal that privacy reasons have been found to justify a partial restriction on the pubhic's right of access to criminal proceedings, but they have not justified restrictions on access to a victim's identity except in the special case of a minor victim of a sex crime. Other First and Sixth Amendinent cases show that a party must assert an imterest of great magnitude-such as safeguarding a person's life-to justify restricting access to identifying

221. See id. at 512. Interestingly, the Supreme Court noted in dictum that jurors who had been raped but who had "declined to seck prosecutiou because of the embarrassment and emotional trauma" associated with disclosure would have a "legitimate" privacy interest. Id. This statement could imply that rape victims who sought prosecution do not have a legitimate privacy interest. Because the Court's stateinent appears in dictuin, this statement cannot be given authoritative weight.

222. See id. at 510-11.

223. See id. at 512; see also In re Dallas Morning News Co., 916 F.2d 205, 206 (5th Cir. 1990) (holding that best inethod for protecting jurors' privacy is to inform venirepersons to make specific requests for confidential interview with judge); Cable News Network, Inc. v. Umited States, 824 F.2d 1046, 1048 (D.C. Cir. 1987) (finding closure of voir dire to protect privacy interests of jurors inappropriate because trial judge made no specific findings that public interrogation would touch on deeply personal matters).

224. 467 U.S. 39 (1984); see supra note 198 (discussing the holding in Waller).

225. See id. at 48. The Court indicated that the state needed to offer specific reasons regarding "whose privacy interests inight be infringed, how they would be infringed, what portions of the tapes unight infringe them, and what portion of the evidence consisted of the tapes"; because these reasons were not offered, closure was unjustified. Id. 
information revealed at a criminal trial. The only interests that suffice for identity restrictions are (1) safeguarding a life, (2) protection from tampering or bias, and (3) a promise of confidentiality made in furtherance of law enforcement to a non-testifying informant.

In conclusion, the cases reviewed in Part III show that a state government has never restricted access to a victim's identity for purely privacy reasons over a defendant's or the public's challenge to gain access to that identity at a criminal proceeding. Keeping information out of the public record is a drastic infringenent on public access. It is only justified when tlie life of a participant in the trial is at stake, or when the fairness of the entire proceeding would be jeopardized by access. The privacy interests of an adult victim, althougl significant, are not worth the cost in public access. Finally, by protecting the privacy interests of a victim over the public's interest in overseeing criminal proceedings the state undermines the victim's own interest in seeing that the criminal justice system operates fairly. This Note concludes that a victim's interest in privacy is not compelling because it is not equal in maguitude to these otlier imterests.

\section{CONCLUSION}

Statutes recently passed in New York, Alaska, and Louisiana may reflect a trend toward increasing restrictions on public access to identifying information about victims. ${ }^{226}$ These new statutes, and similar statutes im existence in otlier states, should be challenged as posing unlawful restrictions on public access. This Note has sliown, using the reasoning in Globe Newspaper Co. v. Superior Court, ${ }^{227}$ that sucli restrictions violate the public's First Amendment right of access to information about the criminal justice system when they are used to cut off access to a victim's identity at any stage of a criminal inatter. This Note has also argued that a victim's privacy interest is not sufficiently compelling to justify infringements on tlie public's right of access. The imterest is nebulous, has an uncertain grounding in law, and undercuts the victim's and the public's imterest in encouraging fairness and opermess in the criminal justice system. As long as opeuness and public access are the cornerstones of the criminal justice system, vigorous public oversiglit, supported by liberal public access to information and proceedings im a criminal matter, operates to everyone's advantage-imcluding the victim's.

226. See supra notes $2-7$ and accompanying text.

227. 457 U.S. 596 (1982). 